\title{
NEW EVIDENCE OF THE EARLIEST DOMESTIC DOGS IN THE AMERICAS
}

\author{
Angela Perri, Chris Widga, Dennis Lawler, Terrance Martin, Thomas Loebel, Kenneth Farnsworth, \\ Luci Kohn, and Brent Buenger
}

\begin{abstract}
The domestication of dogs likely occurred in Eurasia by 16,000 years ago, and the initial peopling of the Americas potentially happened around the same time. Dogs were long thought to have accompanied the first migrations into the Americas, but conclusive evidence for Paleoindian dogs is lacking. In this study, the direct dating of two dogs from the Koster site (Greene County, Illinois) and a newly described dog from the Stilwell II site (Pike County, Illinois) to between 10,190 and 9,630 cal $B P$ represents the earliest confirmed evidence of domestic dogs in the Americas and individual dog burials anywhere in the world. Analysis of these animals shows Early Archaic dogs were medium sized, lived active lifestyles, and exhibited significant morphological variation. Stable isotope analyses suggest diets dominated by terrestrial $C_{3}$ resources and substantial consumption of riverine fish.
\end{abstract}

La domesticación del perro probablemente ocurrió en Eurasia hace 16,000 años, potencialmente alrededor del mismo tiempo que el poblamiento inicial de América. Durante mucho tiempo se pensó que los perros habían acompañado las primeras migraciones humanas hacia el continente americano, pero no se ha encontrado evidencia concluyente de perros paleoindios. La datación directa de dos perros del sitio Koster (condado Greene, Illinois) y un perro recientemente descrito del sitio Stilwell II (condado Pike, Illinois) entre 10.190 y 9630 cal aP representa la evidencia confirmada más temprana de perros domésticos en América y de enterramientos individuales de perros en cualquier parte del mundo. El análisis de estos animales muestra que los perros arcaicos tempranos eran de tamaño mediano y vivían estilos de vida activos, pero que ya exhibían una variación morfológica significativa. Los análisis de isótopos estables sugieren que sus dietas estuvieron dominadas por recursos terrestres de tipo $C_{3}$ y por el consumo sustancial de peces de agua dulce.

$\mathrm{T}$ The domestication and subsequent cultural roles of dogs have been highly debated in the archaeological and genomic literature, especially over the last decade (Drake et al. 2015; Frantz et al. 2016; Freedman et al. 2014; Germonpré et al. 2009; Germonpré et al. 2013; Larson et al. 2012; Morey and Jeger 2015, 2017; Perri 2016a; Perri et al. 2015; Shipman 2015; Thalmann et al. 2013; vonHoldt et al. 2010).
Advances in zooarchaeological, morphometric, and genomic methods have led to a burst of research in the field but have also engendered disagreement regarding the interpretation of data from investigations into their origins. These debates extend to the earliest appearance of domesticated dogs in the Americas and the circumstances leading to their presence in the region, which are unresolved.

\footnotetext{
Angela Perri — Department of Archaeology, Durham University, South Road, Durham DH1 3LE, United Kingdom (angela.r. perri@durham.ac.uk, corresponding author)

Chris Widga - Don Sundquist Center of Excellence in Paleontology, East Tennessee State University, Johnson City, TN 37615, USA

Dennis Lawler - Illinois State Museum Research and Collections Center, 1011 East Ash St., Springfield, IL 62703, USA; Pacific Marine Mammal Center, 20612 Laguna Canyon Rd., Laguna Beach, CA 92651, USA; Center for American Archaeology, Kampsville, IL 62053, USA

Terrance Martin $\square$ Illinois State Museum Research and Collections Center, 1011 East Ash St., Springfield, IL 62703-3500, USA

Thomas Loebel a Illinois State Archaeological Survey, Prairie Research Institute, University of Illinois, Champaign, IL 61820, USA

Kenneth Farnsworth Illinois State Archaeological Survey, Prairie Research Institute, University of Illinois, Champaign, IL 61820, USA

Luci Kohn — Department of Biological Sciences, Southern Illinois University Edwardsville, Illinois 62026, USA

Brent Buenger - Western Archaeological Services, 1600 Dewar Dr., Rock Springs, WY 82901, USA
}

American Antiquity 84(1), 2019, pp. 68-87

Copyright $@ 2018$ by the Society for American Archaeology doi:10.1017/aaq.2018.74 
Though it is now widely accepted that all dogs were domesticated from an ancient wolf ancestor (Freedman et al. 2014; Vilà et al. 1997), findings diverge on the timing, location, and number of domestication sites. The tentative identification of a number of proposed Paleolithic dogs dating from before the Last Glacial Maximum (Germonpré et al. 2009; Germonpré et al. 2012; Germonpré, Sablin et al. 2015, Germonpré, Lázničková-Galetová et al. 2015; Germonpré et al. 2017; Ovodov et al. 2011; Sablin and Khlopachev 2002), some up to 40,000 years ago (Camarós et al. 2016), has led to debate regarding the origins of the human-dog relationship (Boudadi-Maligne and Escarguel 2014; Crockford and Kuzmin 2012; Drake et al. 2015; Morey and Jeger 2015; Perri 2016a).

Despite the suggestion of domesticated dogs much earlier in the Paleolithic, a date of around $16,000 \mathrm{cal} \mathrm{BP}$ is generally accepted as the timing of domestication based on secure archaeological and genomic evidence (Axelsson et al. 2013; Frantz et al. 2016; Freedman et al. 2014; Morey and Jeger 2015; Perri 2016a). Individual domestication locations have been proposed in the Middle East (vonHoldt et al. 2010), Europe (Thalmann et al. 2013), Central Asia (Shannon et al. 2015), and East Asia (Wang et al. 2016), while Frantz and colleagues (2016) suggested a dual origin in East Asia and Europe. The possibility of an independent domestication of dogs in the Americas has been raised by some (Koop et al. 2000; Witt et al. 2015) but rejected by others (Leonard et al. 2002; vonHoldt et al. 2010).

The presence of early dogs in the pre-contact Americas is often assumed to be the result of companion animals arriving from across the Bering Land Bridge with migrating Pleistocene human populations (Fiedel 2005; Schwartz 1998; van Asch et al. 2013). Migrating groups may have used dogs to transport goods and people, work as hunting aids, serve as bed-warmers, warn people of potential danger, ward off predators, and act as sources of food and fur. A recent analysis of dog remains from eastern Siberia suggests that dogs may have been important for hunting and particularly sled transport in the region up to 15,000 years ago (Pitulko and Kasparov 2017), similar to their present functions in some Arctic regions today (Brown et al. 2013).
The earliest human migration into North America south of the ice sheet is proposed via a coastal route between about 25,000 and 15,000 cal BP (Braje et al. 2017; Llamas et al. 2016; Skoglund and Reich 2016) or via a land route through the Ice-Free Corridor by about 15,000 (Munyikwa et al. 2017; Potter et al. 2017). Results of ancient DNA testing suggest ancestral Native American populations split from Siberian populations by 20,000 years ago before moving into eastern Beringia and the Americas (Moreno-Mayar et al. 2018). The earliest archaeological evidence of human presence in the Americas occurs in both North and South America around 14,500 cal BP (Dillehay et al. 2015; Halligan et al. 2016).

There are a number of large canid remains dating to the late Upper Pleistocene from across Beringia and southern Siberia, many of which are suggested to be Paleolithic dogs (see Germonpré et al. 2017 for a review of the Western Beringian and Siberian specimens). These include canids from Ulakhan Sular (ca. 17,200 BP), Diuktai Cave (ca. 17,300-14,100 BP), Afontova Gora-1 (ca. 16,900 BP), Verkholenskaia Gora (ca. 14,900 BP), Berelekh (ca. 14,100 BP), Little John (ca. 14,000 BP; Easton et al. 2011), McDonald Creek (ca. 14,000-12,600 BP; Mueller et al. 2015), Nikita Lake (ca. 13,800 BP), Ushki-I (ca. 12,800 BP), and Ust'Kiakhta (ca. 12,300 BP). At present, the taxonomy and interpretation of many of these specimens is contested or inconclusive. Others have yet to be further evaluated.

Although the arrival of domesticated dogs with an initial human migration has been the most reasonable explanation for their presence in the Americas, evidence for Paleoindian dogs has proven elusive. Previously, Jaguar Cave (Idaho) was thought to hold the earliest domestic dog remains in the Americas at over 10,000 years old (Lawrence 1967). However, when dated directly, the remains proved to be only 3,000-4,000 years old (Gowlett et al. 1987). Similarly, Beebe (1980) reported early dog remains dating to around 20,000 years ago from Old Crow Basin (Yukon Territory), but later dating demonstrated that this dog is of late Holocene age (Harington 2003). While there are suggestions of domesticated dogs over 10,000 years old from a few North American sites (Grayson et al. 1988; 
Haag 1970; Jenkins et al. 2013; Lyman 2013; Saunders and Daeschler 1994; Stanford 1978; Walker and Frison 1982), these canid remains have not benefited from recent chronological or morphological evaluations.

Fiedel (2005) suggested that the lack of dog remains during the Paleoindian period is not an indication that dogs were absent but is rather the result of their ephemeral nature. While this is a distinct possibility, the earliest appearance of domestic dogs at Early Archaic sites in the midcontinent (Morey and Wiant 1992; Walker et al. 2005) raises questions regarding their origins and routes into the Americas. At Hinds Cave (Texas), Tito and colleagues (2011) reported finding a small bone fragment within a human coprolite, which they determined as the earliest evidence for dogs in the Americas. Genomic analysis was performed, and the specimen was dated to around 9,200 cal BP. Other early examples of domesticated dogs include specimens from Modoc Rock Shelter in Illinois (ca. 8,400 cal BP; Ahler 1993), Dust Cave in Alabama (ca. 8,400 cal BP; Walker et al. 2005), Rodgers Shelter in Missouri (ca. 8,800 cal BP; McMillan 1970), and Koster in Illinois (ca. 9,500 cal BP; Brown and Vierra 1983; redated in this study). Together, these specimens constitute the corpus of the earliest confirmed archaeological dog record in the Americas.

The arrival of dogs in the Americas has important cultural and ecological implications. Dogs were the first invasive species (along with humans) and domesticates in the Americas, potentially affecting populations of small mammals through predation, other species of Canis through hybridization, and other carnivores through competition or disease transmission (Doherty et al. 2017). They may have also contributed to important adaptations in hunting and mobility during the peopling of the Americas and into the Pleistocene-Holocene transition.

Here, we present the identification, zooarchaeological analysis, stable isotope analysis, and direct radiocarbon dating of a new isolated dog burial from Stilwell II, an Early Archaic site in the lower Illinois River valley. We also present new direct radiocarbon dates and stable isotope results for dogs from the nearby Koster site and three additional Archaic dogs from the region.
These dates confirm that the Stilwell II and Koster dogs represent the earliest directly dated evidence for domesticated dogs in the Americas and the oldest intentional individually buried dogs known worldwide. Similar dog burials only appear in hunter-gatherer contexts approximately 1,000 years later (Perri 2014; Perri 2016b). Importantly, we contribute to an emerging analytical framework for understanding the behavior and life history of these canids. Our analyses (zooarchaeology, paleopathology, morphology, and stable isotopes) lend insight into what these dogs looked like, how they lived, and their roles within Early Archaic communities.

\section{Site Backgrounds}

\section{The Koster Site}

The Koster site (11GE4) is in a minor tributary valley of the lower Illinois River in Greene County, Illinois (Figure 1). The site is multicomponent and highly stratified with cultural deposits spanning the Early Archaic to Mississippian, providing a nearly continuous record of Holocene human occupation (Brown and Vierra 1983). The site was excavated continuously over a ten-year period and is one of the most studied sites in the lower Illinois River valley (e.g., Butzer 1978; Hajic 1990; Komar and Buikstra 2003).

Three isolated dog burials (cf. Perri 2017) in shallow, well-demarcated pits were identified from Horizon 11, one of the Early Archaic phases at Koster (Figure 2). There was also a fourth burial, likely associated with a later period (Hill 1972; Morey and Wiant 1992), and a fifth burial is reported (Neusius 1996), the remains of which are not currently present in the Illinois State Museum collection. The skeletons of the three dogs from Horizon 11 were complete and articulated, and they lacked evidence of butchering or skinning (Morey and Wiant 1992). Given their presence in Horizon 11 and association with a nearby charcoal date (Brown and Vierra 1983), the dogs were attributed to the terminal Early Archaic. Though this date is commonly reported as 8,500 years ago (e.g., Morey and Wiant 1992:225), the calibrated age based on the 


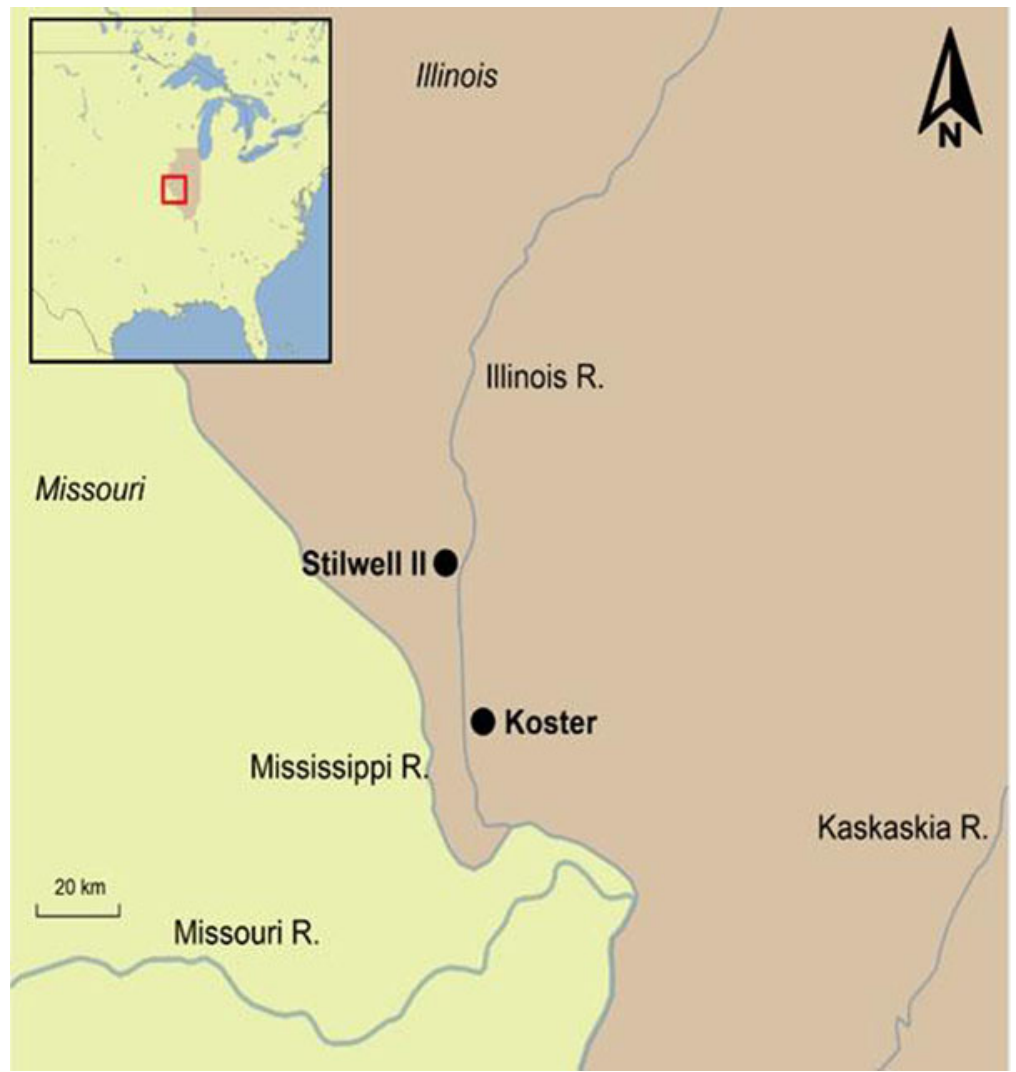

Figure 1. Location of the Koster and Stilwell II sites.

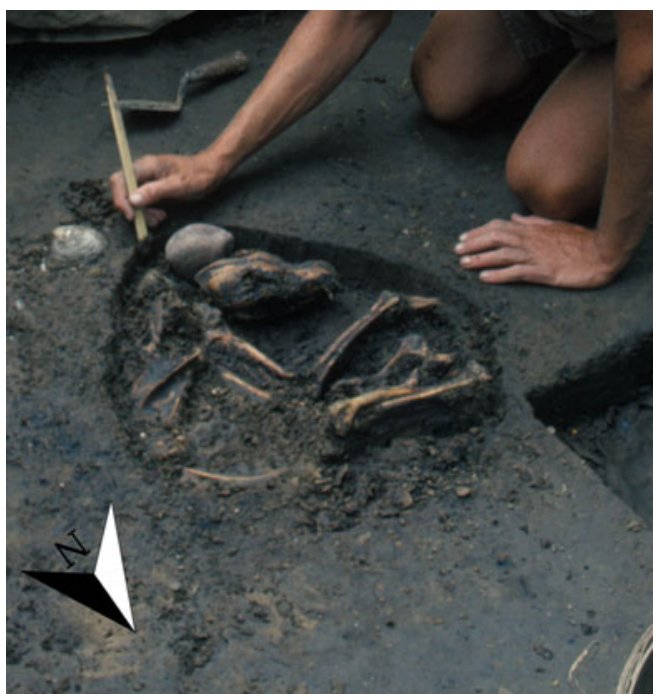

Figure 2. Excavation of the Koster F2256 dog burial (photograph by Del Baston, courtesy of the Center for American Archeology). associated charcoal ${ }^{14} \mathrm{C}$ dates is about $9,500 \mathrm{cal}$ BP. These specimens are often cited as the earliest domesticated dogs and occurrences of intentional dog burials in the Americas (Fiedel 2005; Lapham 2010; Morey 2010; Morey and Wiant 1992; Walker et al. 2005).

\section{The Stilwell II Site}

The Stilwell II site (11PK1044) was discovered in 1960 when road-grading operations cut through an alluvial fan in Pike County, Illinois, about $35 \mathrm{~km}$ from the Koster site. Gregory Perino collected lithic artifacts and faunal remains from what he described as two living areas indicated by a dark layer of soil $15.2 \mathrm{~cm}$ thick and $6.1 \mathrm{~m}$ long that was exposed at the base of a 4.3 m cutbank (Perino 1970:119). He subsequently recovered a dog burial in the northern area of the site and a human burial in the southern area. The dog burial (Figure 3), which 


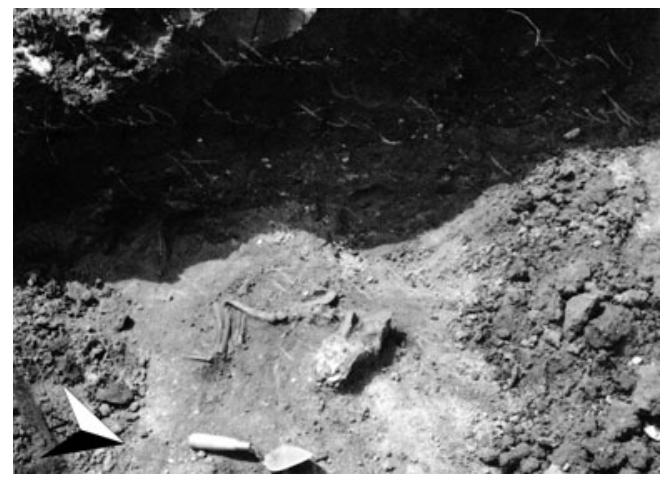

Figure 3. The Stilwell II dog burial in situ (courtesy of the Illinois State Museum).

was complete and articulated (Perino 1970, 1977), was curated at the Illinois State Museum. The faunal remains collected by Perino and others from later excavations done by the Illinois State Archaeological Survey include white-tailed deer, turkey, turtle, small birds, vole, squirrel, fish, and mussel. After the two rescue excavations in 1960 and 1962, Perino published very little about the site and left no field notes or maps. The Illinois State Archaeological Survey began reexcavating the site in 2015 , and that is ongoing (see Supplemental text).

\section{Materials and Methods}

\section{Zooarchaeology, Morphology, and Paleopathology}

The Koster and Stilwell II dogs were analyzed in the zooarchaeology laboratory at the Illinois State Museum's Research and Collections Center, where they are curated. All skeletal specimens were examined to note the condition of epiphyseal closure, presence of cut marks, damage by carnivore or rodent gnawing, and exposure to fire. Analysis of shoulder height relies on the regression equations of Harcourt (1974), and body-mass estimates use the methods presented by Losey and colleagues (2014, 2016). Researchers have previously published comprehensive measurement data, burial information, and paleopathology for the Koster dogs (Lawler et al. 2016; Morey 1992, 2006; Morey and Wiant 1992), which is not repeated here. Recent analysis of ancient DNA from one Koster specimen confirms a link to Eurasian domesticated dogs, likely originating in Siberia (Ní Leathlobhair et al. 2018; Thalmann et al. 2013). Recovery of ancient DNA from the Stilwell II dog has failed thus far.

Though little documentation exists for the site, Perino (1970:119) is clear that the remains of the Stilwell II dog were found in a shallow, intentional burial in what he described as the floor of a living area. The only in situ photograph of the dog shows an articulated skeleton as an isolated burial (Figure 3) with a northwestsoutheast orientation (head facing west). The front legs appear to be tucked partly under the body.

Following Von den Driesch (1976), we provide all possible skeletal measurements for the Stilwell II dog and have retaken all possible measurements from the two Koster dogs (F2256 and F2357) dated in this study (Supplemental Table 1). These measurements were compared to a sample of seven Archaic dogs from Iowa and Illinois (Supplemental Table 3). Modern wild canids (C. latrans, $C$. lupus) curated in the Illinois State Museum, the University of Kansas Biodiversity Institute, and the East Tennessee Museum of Natural History were also included in osteometric analyses to illustrate the morphological differences between domesticated and wild taxa. Three-dimensional models of the Koster F2256 and Stilwell II mandibles are available for download (see Data Availability Statement).

Observations of the appendicular skeleton include overt and incipient pathology. We define incipient pathological changes as very mild or very early changes not easily visualized by standard radiographic methods and not clarified substantially by standard computed tomography. Each bone was examined directly, supported by magnification as necessary. Microcomputed tomography has been conducted with some of the specimens as parts of other studies (Lawler et al., 2016). All specimens were photographed. Observations were recorded by location within bone, resulting in multiple scores for given joint components (Supplemental Table 2).

\section{Radiocarbon Dating and Stable Isotopes}

Small rib fragments (1-2 cm in length) from the Koster and Stilwell II dogs were submitted to the 
University of Arizona AMS lab (Tucson, Arizona) or Rafter Radiocarbon lab (Lower Hutt, New Zealand) for radiocarbon dating (Table 2). In both cases, collagen was extracted using a modified Longin technique of acid demineralization followed by removal of organic contaminants using a weak basic solution (Longin 1971). Samples were combusted and further purified in a dedicated gas line and converted to graphite targets. These targets were analyzed using the accelerator at the Department of Physics, University of Arizona (USA) and the National Isotope Centre, GNS Science (New Zealand), respectively. All ${ }^{14} \mathrm{C}$ results are calibrated as 2-sigma age ranges with the Intcal13 dataset (Reimers et al. 2013) using Calib 7.1 html (Stuiver et al. 2017).

Bone-collagen stable isotope samples followed the same laboratory preparation methods as those prepared for ${ }^{14} \mathrm{C}$ but were analyzed on a continuous-flow gas-ratio mass spectrometer coupled to an elemental analyzer. At the University of Arizona lab, standardization is based on acetanilide for elemental concentration, NBS-22 and USGS-24 for $\delta^{13} \mathrm{C}$, and IAEA-N-1 and IAEA-N-2 for $\delta^{15} \mathrm{~N}$. Precision is better than \pm 0.1 for $\delta^{13} \mathrm{C}$ and \pm 0.2 for $\delta^{15} \mathrm{~N}$. At the Rafter lab, standardization is based on leucine $(-22.7 \%$ o for $\delta^{13} \mathrm{C}, 2.2 \%$ or $\left.\delta^{15} \mathrm{~N}\right)$, and caffeine $(-37.9 \%$ o for $\delta^{13} \mathrm{C},-7.4 \%$ ofor $\delta^{15} \mathrm{~N}$ ). Precision for these measurements is $\pm 0.3 \%$ or $\delta^{15} \mathrm{~N}$ and $\pm 0.2 \%$ o for $\delta^{13} \mathrm{C}$. All $\delta^{13} \mathrm{C}$ results are reported relative to VPDB, and all $\delta^{15} \mathrm{~N}$ results are reported relative to N-Air. A third Koster dog (222D) from Horizon 11 was also included in the isotopic analyses.

These data are compared to additional Early and Middle Archaic dog samples from Modoc Rockshelter in Illinois and Rodgers Shelter in Missouri, as well as published archaeological dog and human stable isotope data from the lower Illinois River valley and American Bottom (Carbaugh et al. 2018; Fort et al. 2016; Hargrave et al. 2006; Hedman et al. 2002). A dataset consisting of midwestern wolves (Fox-Dobbs et al. 2007), midwestern deer (Cormie and Schwarcz 1994), and freshwater fish from lower Illinois River valley archaeological assemblages dating to before the local use of maize (Brugam et al. 2017) is also included to illustrate general dietary trends in archaeological dog samples. The modern deer dataset is divided into two groups representing animals with very little $\mathrm{C}_{4}$ contribution to the diet $\left(\mathrm{C}_{3}\right.$ deer $)$ and those with $>10 \% \mathrm{C}_{4}$ contribution to the diet $\left(\mathrm{C}_{4}\right.$ deer).

\section{Results}

\section{Zooarchaeology, Morphology, and Paleopathology}

On the Stilwell II specimens, faint root etching was noted on several of the long bones, whereas only two occurrences of rodent gnawing were observed. No cut marks from dispatch wounds (e.g., on the atlas vertebra) or dismemberment (e.g., cuts near articular ends) were present on the skeleton. The dog was an adult of undetermined age, and the absence of a baculum from the otherwise well-represented posterior bones suggests the animal was a female.

Since it is a relatively complete skeleton, the Stilwell II dog has the potential to provide anatomical insights into the size and morphology of early North American dogs. It had an estimated shoulder height between 504 and $517 \mathrm{~mm}$, based on radial (RDgl) and tibial (TAgl) length (Table 1; Harcourt 1974). Losey and colleagues recently suggested improved methods for bodymass estimation based on measurements of craniodental (2014) and limb elements (2016). Application of these regression equations to the Stilwell II dog resulted in widely varying estimates (17-32 kg). Following Losey and colleagues (2016), we prefer body-mass estimates that are based on elements relating directly to locomotion, such as limb elements. Estimates of body mass based on the humerus (distal breadth; HMbd) and radius (proximal breadth; RDbp) are both $17.1 \mathrm{~kg}$ (Table 1), similar in mass and build to a small, modern English setter. Dogs from the nearby Koster site are slightly shorter (with shoulder heights between 439 and $463 \mathrm{~mm}$ ) and more lightly built (12-14 kg; Figure 4).

Mandibular morphology varies significantly between the Stilwell II and Koster dogs (Figure 5). The Stilwell II dog mandible is robust with relatively small carnassial molars and a deep mandibular body. Dog mandibles from the Koster site, however, are more gracile, with large 
Table 1. Shoulder Height and Body Mass Estimates of the Koster and Stilwell II Dogs.

\begin{tabular}{lllllll}
\hline & \multicolumn{2}{l}{ Shoulder Height $^{\mathrm{a}}$} & \multicolumn{2}{l}{ Body Mass $^{\mathrm{b}}$} & \multicolumn{2}{l}{ Body Mass $^{\mathrm{b}}$} \\
\hline Measurement & Radial length & Tibial length & VDDm18 & VDDm19 & Humerus distal length & Radial proximal breadth \\
Koster F2256 & 450.7 & 439.8 & 13.4 & 15.3 & 12.5 & 13.6 \\
Koster F2357 & 463.1 & 453.0 & 16.5 & 16.9 & 12.8 & 14.3 \\
Stilwell II & 517.2 & 504.6 & 22.5 & 32.3 & 17.1 & 17.1 \\
\hline
\end{tabular}

${ }^{a}$ Data from Harcourt (1974) in mm.

${ }^{\mathrm{b}}$ Data from Losey et al. (2014) in kg.

${ }^{\mathrm{c}}$ Data from Losey et al. (2016) in $\mathrm{kg}$.

VDDm18 and VDDm19 from mandibular measurements in Von den Driesch (1976). VDDm18 is the vertical height of the ramus and VDDm19 is the vertical height of the mandibular body behind the M1.

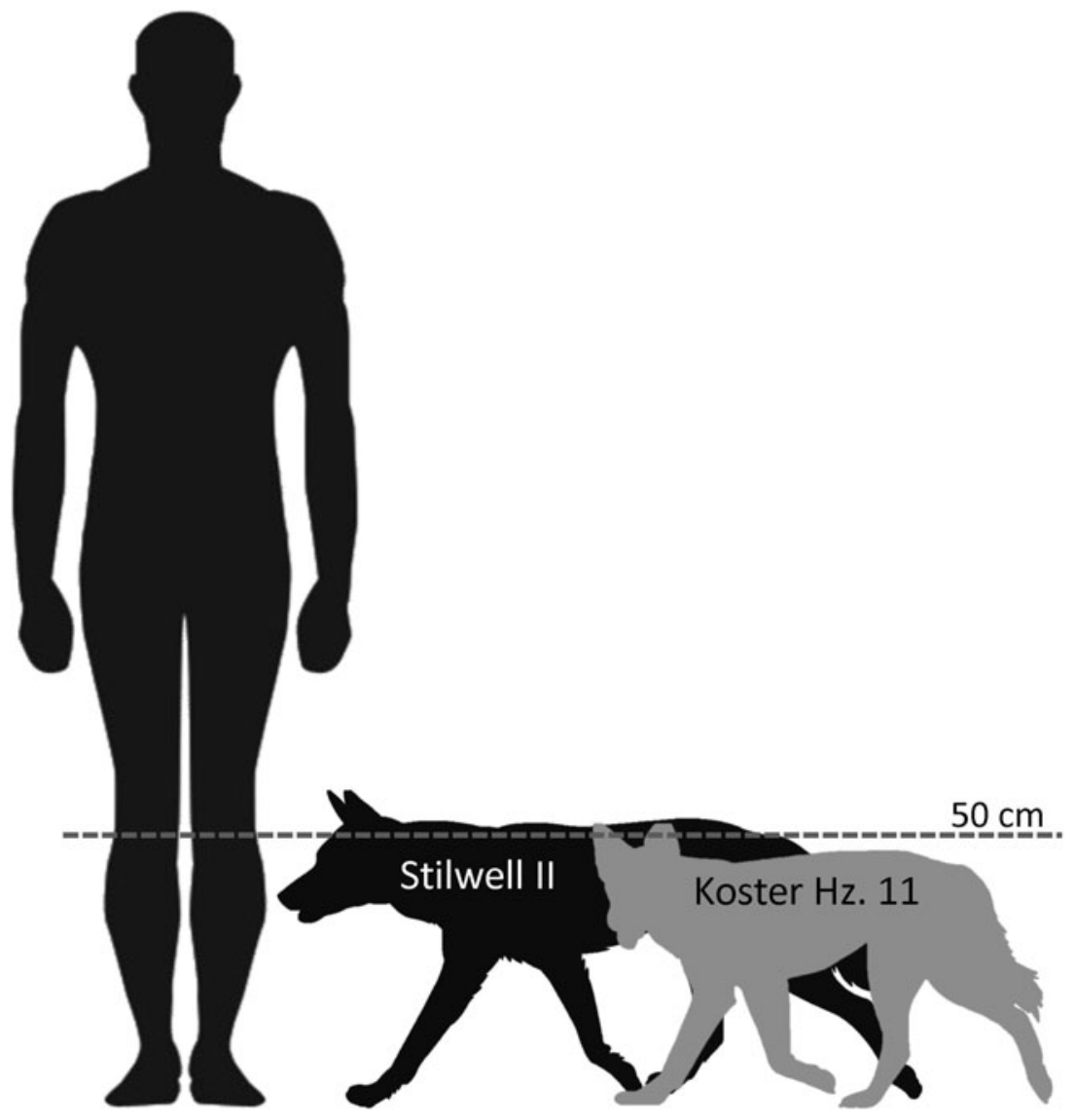

Figure 4. Relative size of the Stilwell II and Koster dogs.

carnassial molars and shallow bodies, relative to their size.

Observations of the Stilwell II dog's axial skeleton included multifocal periodontalperiosteal disease and severe tooth wear. The first and second molars exhibit extreme wear (Figure 6), and the right lower canine is worn nearly blunt. Damage of this type depends partly on genetic susceptibility (e.g., modern smallbreed dogs), and on diet and habits such as chewing on bones. The dog could have experienced several complications of chronic oral cavity disease. The rough enlargement of perialveolar mandibular bone below the mandibular arcades signals gingival and periodontal disease. DeBowes and colleagues (1996) showed that 


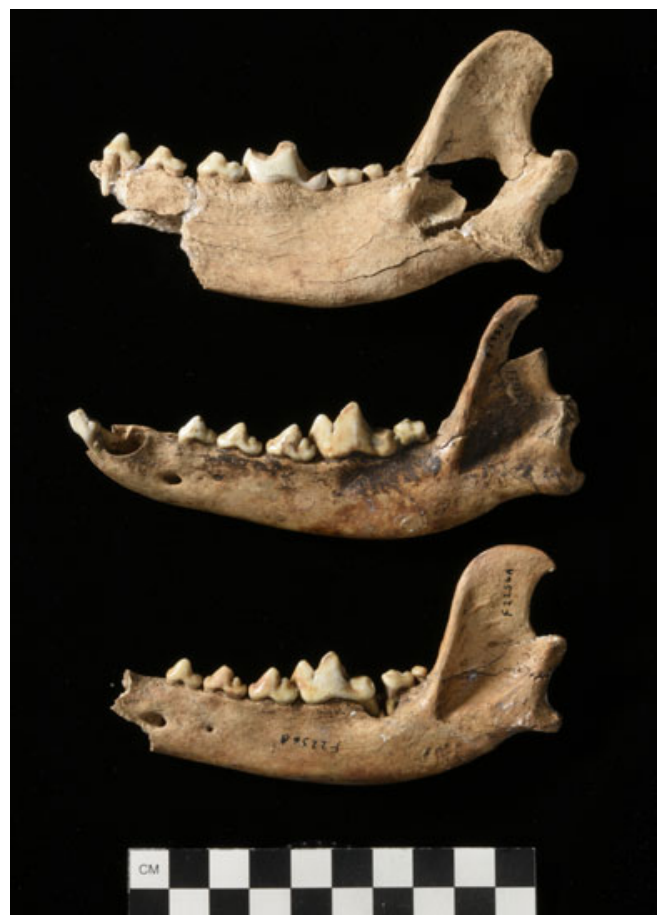

Figure 5. Comparison of left mandibles from (top to bottom) the Stilwell II, Koster F2357, and Koster F2256 dogs.

multiple organ pathology can be related to oral cavity diseases such as gingivitis and periodontitis. Significant associations were found between periodontitis and diseases of the kidney glomerular and interstitial tissue; myocardium, especially papillary muscle; and hepatic parenchyma. The likely explanation is recurring bacteremia originating in the oral tissue (DeBowes et al. 1996). Without regular dental care, modern domestic dogs commonly develop a similar oral pathology, and from the perspective of modern veterinary medicine, the Stilwell II dog would have been very uncomfortable.

Deviations of spinous processes were observed on seven vertebrae. Prevailing opinion has been that domestic dog vertebral spinous process deviations were caused by carrying packs or pulling travois (Darwent and Gilliland 2001; Walker et al. 2005; Warren 2000). However, it has been shown recently that thorough differential diagnosis of these features yields multiple possible pathological causes or pseudopathologies (Lawler et al. 2016). Furthermore, the anatomical locations of affected vertebrae are

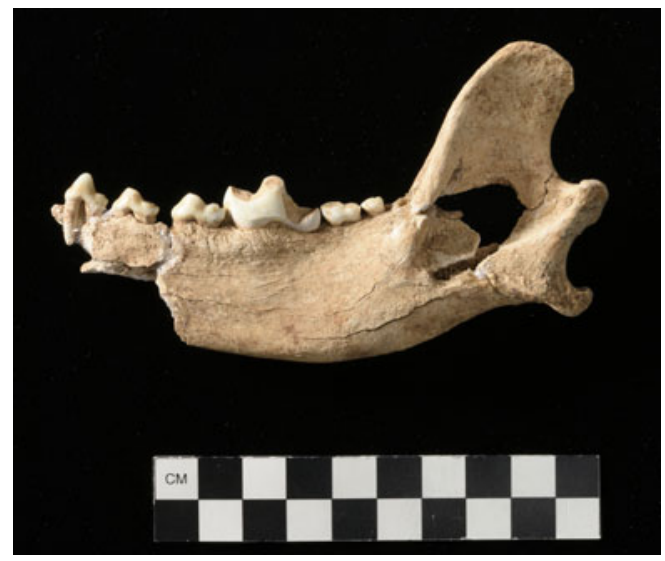

Figure 6. The left mandible of the Stilwell II dog showing advanced tooth wear.

protected by the caudodorsal neck ligament, tendon, and muscle mass (Miller et al. 1979) or lie below the protective transverse plane of the wings of the ilia. Thus, these vertebrae are not susceptible to injury related to carrying packs or pulling travois (Lawler et al. 2016; Supplemental Table 2). A recent study of arctic foxes supports the notion that vertebral asymmetry can be a part of normal morphological variation in at least Canidae (Mustonen et al. 2017).

The limbs yielded observations of normal, incipient, and overt pathological changes. The metapodials and phalanges yielded observations of incipient pathology (Supplemental Table 2). The summed changes are consistent with an active lifestyle and do not differ qualitatively from those seen in modern adult dogs (Lawler and Evans 2016; Lawler et al. 2017; Mustonen et al. 2017).

\section{Radiocarbon Dating and Stable Isotopes}

The Stilwell II and Koster specimens previously had not been directly radiocarbon dated. Because they were discovered within Horizon 11, three dogs from Koster were associated with five Horizon 11 radiocarbon $\left({ }^{14} \mathrm{C}\right)$ assays yielding dates between 8,480 \pm 110 BP (ISGS-236) and 8,130 \pm 90 BP (ISGS-1065; Brown and Vierra 1983:187), but often cited as 8,500 years ago (e.g., Morey and Wiant 1992). A fourth undated Koster dog likely comes from a later Archaic occupation. Here, we present three new direct ${ }^{14} \mathrm{C}$ dates from the Stilwell II dog and two Koster Horizon 11 dogs (F2256 and F2357; Table 2). 
Table 2. Bone Collagen Radiocarbon Dates and Stable Isotope Values.

\begin{tabular}{|c|c|c|c|c|c|c|}
\hline $\begin{array}{l}\text { Laboratory Tracking } \\
\text { Number }\end{array}$ & Specimen & ${ }^{14} \mathrm{C} \mathrm{BP}$ & $\begin{array}{l}\text { 2-sigma, cal } \\
\mathrm{BP}\end{array}$ & $\begin{array}{l}\delta^{13} \mathrm{C} \\
(\% o)\end{array}$ & $\begin{array}{l}\delta^{15} \mathrm{~N} \\
(\% o)\end{array}$ & $\begin{array}{l}\text { Carbon to Nitrogen } \\
\text { Ratio }\end{array}$ \\
\hline AA101127 & Stilwell II dog & $8,840 \pm 80$ & $10,190-9,630$ & -23.0 & 9.1 & 3.4 \\
\hline NZA37136 & $\begin{array}{r}\text { Koster dog } \\
(\mathrm{F} 2256)\end{array}$ & $8,790 \pm 30$ & $10,110-9,680$ & -22.6 & 8.4 & 3.4 \\
\hline NZA37135 & $\begin{array}{c}\text { Koster dog } \\
\text { (F2357) }\end{array}$ & $8,820 \pm 30$ & $10,130-9,700$ & -22.9 & 8.6 & 3.4 \\
\hline ISM2015-42 & Koster dog (222D) & - & - & -22.4 & 8.6 & 2.9 \\
\hline
\end{tabular}

Lyophilized samples from all three dogs had white, fluffy appearances, and carbon to nitrogen ratios $(\mathrm{C}: \mathrm{N})$ were within the range of modern mammalian collagen (Tuross et al., 1988), suggesting well-preserved collagen.

Koster dog F2256 dates to 8,790 \pm 30 BP (10,110-9,680 cal BP), Koster dog F2357 dates to $8,820 \pm 30 \mathrm{BP}(10,130-9,700 \mathrm{cal} \mathrm{BP})$, and the Stilwell II dog dates to $8,840 \pm 80 \mathrm{BP}$ $(10,190-9,630$ cal BP). The chronological differences between the Stilwell II and Koster individuals are not statistically significant at the scale of ${ }^{14} \mathrm{C}$ dating. These new dates range several hundred years earlier than previously associated dates for the Koster dogs and add another lower Illinois River valley dog to the record of early precontact dogs.

The stable isotope values for the Stilwell II dog and three Koster Horizon 11 dogs are presented in Table 2 . These data are tightly clustered in isotope space, with an average $\delta^{13} \mathrm{C}_{\text {coll }}$ value of $-22.7 \% \circ(\sigma=0.3)$ and an average $\delta^{15} \mathrm{~N}_{\text {coll }}$ value of $8.7 \%$ o $(\sigma=0.3)$.

\section{Discussion}

\section{Morphological Variation in Early North American Dogs}

Most morphological work on North American dogs has focused on cranial shape (Morey 1992, 2010; Morey and Wiant 1992; Olsen 1985; Walker et al. 2005); however, measurements on mandibles (Bozell 1988; Walker and Frison 1982) and limb elements (Morey and Aaris-Sørensen 2002) have also been examined. Relative to wild canids, North American dogs generally exhibit shortened muzzles with accompanying changes to dental and mandibular elements. Smaller body size and the size of certain elements (i.e., carnassial molars) have been attributed to domestication (Morey 2010), though recent work has reevaluated the usefulness of many so-called domestication markers (Ameen et al. 2017; Drake et al. 2017; Janssens et al. 2016). Unfortunately, in the zooarchaeological record, crania are fragile and often poorly preserved. Although relatively complete crania are present at the Koster site, the Stilwell II dog is represented only by cranial fragments despite field documentation indicating that a complete skull was found.

To better understand morphological variability among early midwestern dogs, we use a limited set of mandibular measurements from a larger sample of Archaic midwestern domesticated dogs and modern wild Canis spp. (Supplemental Table 3). In this dataset, Archaic midwestern dogs generally have deeper mandibular bodies (i.e., greater height of the mandible behind the carnassial $\mathrm{M}_{1}$; Von den Driesch 1976:60) relative to the length of the carnassial molar (Von den Driesch 1976:60; Figure 7). The Stilwell II, Simonsen and one of the Modoc specimens have dog-sized carnassial molars but relatively deep, wolf-like mandibles. Three Koster and two Modoc dogs also have deep mandibles relative to carnassial size, although they are much smaller specimens. Coyote-dog hybrids (coydogs) generally plot near the archaeological dogs in this morphospace, suggesting that hybrid individuals may be difficult to distinguish through morphology alone. It is also possible that some early archaeological dog samples are from hybrid individuals, as suggested by recent analysis of ancient DNA from one Koster dog (Ní Leathlobhair et al. 2018).

Even this limited sampling of Archaic dogs allows some comparative insight into early dog morphology among contemporaneous specimens 


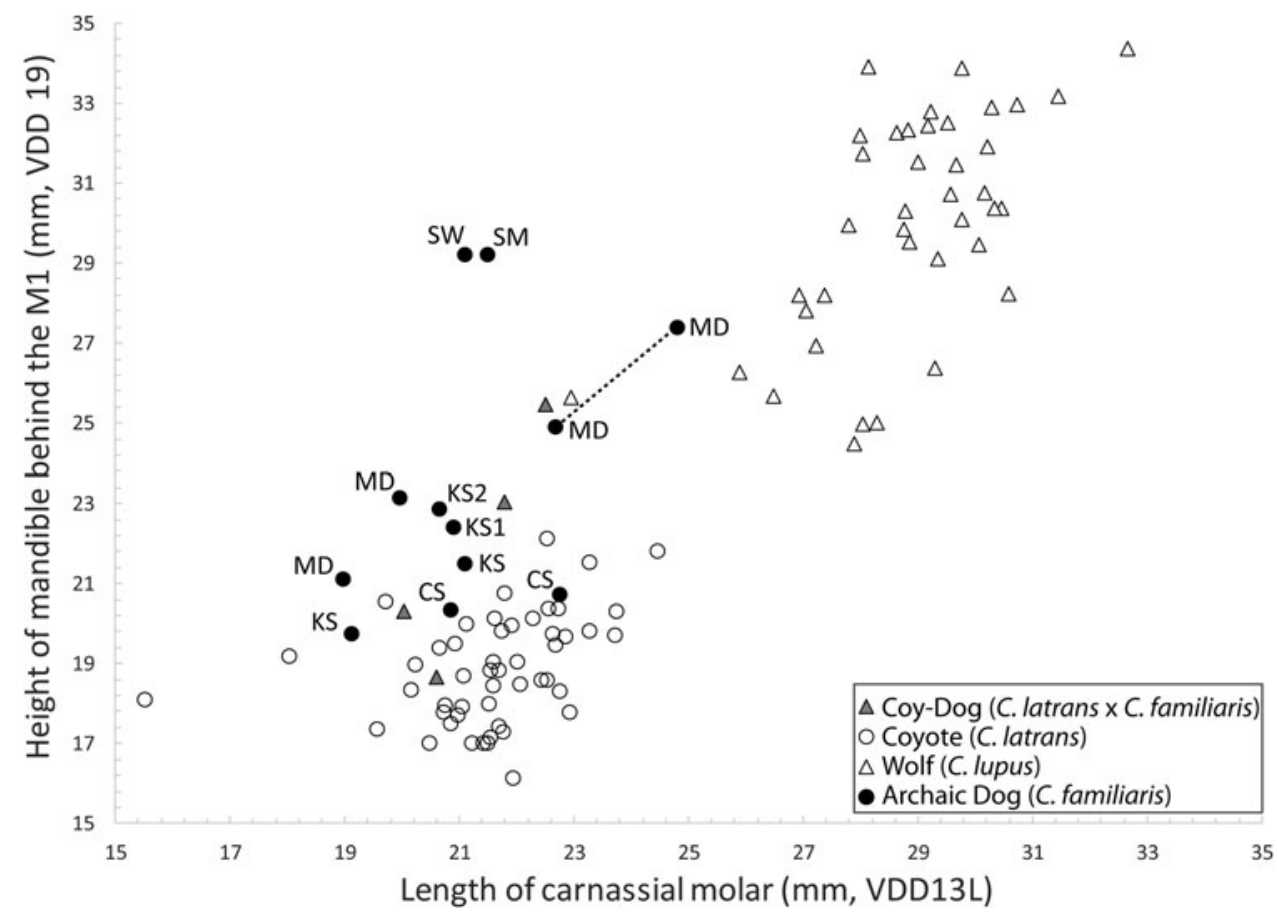

Figure 7. Relationship between carnassial length (Von den Driesch 1976, measurement 13L) and mandibular body height (Von den Driesch 1976, measurement 19) among different Canis groups. CS = Cherokee Sewer, Iowa; MD = Modoc Rock Shelter, Illinois; KS = Koster, Illinois (KS1 and 2 included in this study); SM = Simonsen, Iowa; SW = Stilwell II, Illinois. The dotted line connects the left and right mandibles of the same individual. See Supplemental Table 3.

as well as those from several different periods represented at the same site. For example, the three dogs from Modoc Rock Shelter show a significant variation in mandibular height and length of carnassial molars (Figure 7). The largest dog dates to 8,560-8,200 cal BP (Supplemental Table 3) but exhibits intra-individual variation between the left and right mandible (shown via dotted line, Figure 7). Another dog from the site dates to 5,710-5,330 cal BP and has much smaller molars and a more gracile mandible. A third undated (likely Archaic) dog falls between these two. Similarly, from the Koster site, the two contemporaneous dogs and a third undated but likely contemporaneous dog all cluster. A fourth dog, likely from a later period (Hill 1972; Morey and Wiant 1992), is smaller than those three in both measurements (Figure 7).

Though only a small sample, the distinct differences between the mandibles of the robust Stilwell II dog and the more gracile Koster dogs (Figure 5), from individuals geographically and temporally indistinguishable, suggest variation in the earliest American dogs. This is perhaps unsurprising, given the morphological variation seen at sites from similar periods in eastern Siberia (Pitulko and Kasparov 2017) and recent analysis of ancient DNA that shows at least two distinct ancient American dog haplogroups splitting between 16,400 and 12,900 years ago (Ní Leathlobhair et al. 2018). The probable female sex of the larger Stilwell II dog suggests the morphological differences are not the result of sexual dimorphism, especially given that the similarly gracile Koster dogs include a female (F2256) and a male (F2357; Morey and Wiant 1992). Similar morphological variation is seen in the two contemporaneous Middle Archaic dogs from Iowa (Figure 7): one is more robust, like the Stilwell II dog, and the other is more gracile, like the Koster dogs. Though this variation may be the result of morphologically distinct American dog lineages, it may also arise from local admixture with wild 
canids, such as coyotes and wolves, leading to rapid variation within a more homogenous initial dog population.

\section{Hybridization of Early North American Dogs}

Genomic work on wild canid populations has demonstrated that all North American Canis spp. could interbreed, often to a significant degree (Monzón et al. 2014; Wayne and Jenks 1991). Although we analyze these taxa as distinct groups, it is likely that some of these specimens show admixture of different species, even in groups made up of modern museum specimens of "known" taxonomic affinity. For example, a recent analysis of ancient DNA from one of the Koster dogs we dated (F2256) revealed that although the specimen clusters with all other precontact North American dog material analyzed (spanning about 9,000 years), it also showed evidence for potential admixture with a midwestern coyote (Ní Leathlobhair et al. 2018). This may account for the morphological variation seen between the Koster dogs and the Stilwell II dog, which were concurrent in space and time.

For these reasons, we consider the present study as merely illustrative of general morphological trends in archaeological Canis. Combined genomic and morphological approaches have the potential to answer many questions about North American dog populations. However, these techniques are just being applied rigorously to questions of early dogs in the Americas.

\section{Environment and Diet}

The landscape in the lower Illinois River valley roughly $10,000 \mathrm{cal} \mathrm{BP}$ was a mesic, fire-sensitive woodland (Baker et al. 1992, Nelson et al., 2006). Although $\mathrm{C}_{4}$ plants were present in small numbers at that time $\left(<22 \% \mathrm{C}_{4}\right)$, they began to dominate upland floras after about 9,000 cal BP with the spread of the tallgrass prairie (Nelson et al. 2006). Within this environment, early Holocene human dietary protein was predominantly acquired from terrestrial and riverine sources (Styles and McMillan 2009) and $\delta^{13} \mathrm{C}$ values would have ranged from $-22 \%$ o to $-38 \%$ o (average $=-26.5 \%$; ; Tieszen 1991; Tieszen and Fagre 1993).
The $\delta^{15} \mathrm{~N}$ of bone collagen $\left(\delta^{15} \mathrm{~N}_{\text {coll }}\right)$ in the Midwest is influenced strongly by trophic-level fractionation, with a difference of about 3\%o between predators and their prey (Hedman et al. 2002; Schoeninger and DeNiro 1984). Although landscape aridity can also affect the $\delta^{15} \mathrm{~N}$ of primary consumers (Heaton et al. 1986), the mesic environment of the lower Illinois River valley approximately 10,000 years ago suggests that aridity would have contributed little to local $\delta^{15} \mathrm{~N}_{\text {coll }}$ values. However, seasonality may influence $\delta^{15} \mathrm{~N}_{\text {coll }}$ values through the recycling of body tissues due to periodic nutritional stress (Polischuk et al. 2001).

Most isotopic studies of human diets in the valley have focused on the dietary transition from hunting and gathering to growing maize (Buikstra et al. 1994; Emerson et al., 2005; Hedman et al. 2002) and have attempted to track the dietary effect of maize, $\mathrm{a}_{4}$ grass, on populations that previously depended on a diet dominated by $\mathrm{C}_{3}$ sources. However, the $\delta^{15} \mathrm{~N}$ of human diets has recently received more attention (Froehle et al. 2012; Hedman et al. 2002). Schober (1998, cited in Hedman et al. 2002) noted that $\delta^{15} \mathrm{~N}_{\text {coll }}$ of midwestern communities with a maize-dominated diet $\left(\delta^{15} \mathrm{~N}_{\text {coll }}=\right.$ $+9.5 \%$ o) were not significantly different from coeval groups that did not rely heavily on domesticates $\left(\delta^{15} \mathrm{~N}_{\text {coll }}=+8.9 \%\right.$ )

The Koster and Stilwell II dog isotope values reflect unsurprising results for early Holocene pre-maize diets in the region. Low $\delta^{13} \mathrm{C}$ values suggest terrestrial $\mathrm{C}_{3}$ resources, while high $\delta^{15} \mathrm{~N}$ values may signal consumption of freshwater resources (Brugam et al. 2017), human feces (Katzenberg 1989), and/or higher overall $\delta^{15} \mathrm{~N}$ values in local prey. Early Archaic dog $\delta^{15} \mathrm{~N}$ values are significantly greater than the single Early Archaic human value in the region (Kaskaskia Mine, Randolph County, Illinois; Hargrave et al., 2006), but are more consistent with Middle and Late Archaic human and dog paleodiets (Figure 8). Since these values generally fall outside the range of modern wolves with a $\mathrm{C}_{3}$ terrestrial diet and are within the range of pre-maize freshwater fish from the Illinois River, it is likely that freshwater fish were a significant part of the Early Archaic dog's diet.

On a larger scale, the variability in both human and $\operatorname{dog} \delta^{15} \mathrm{~N}$ values throughout the 


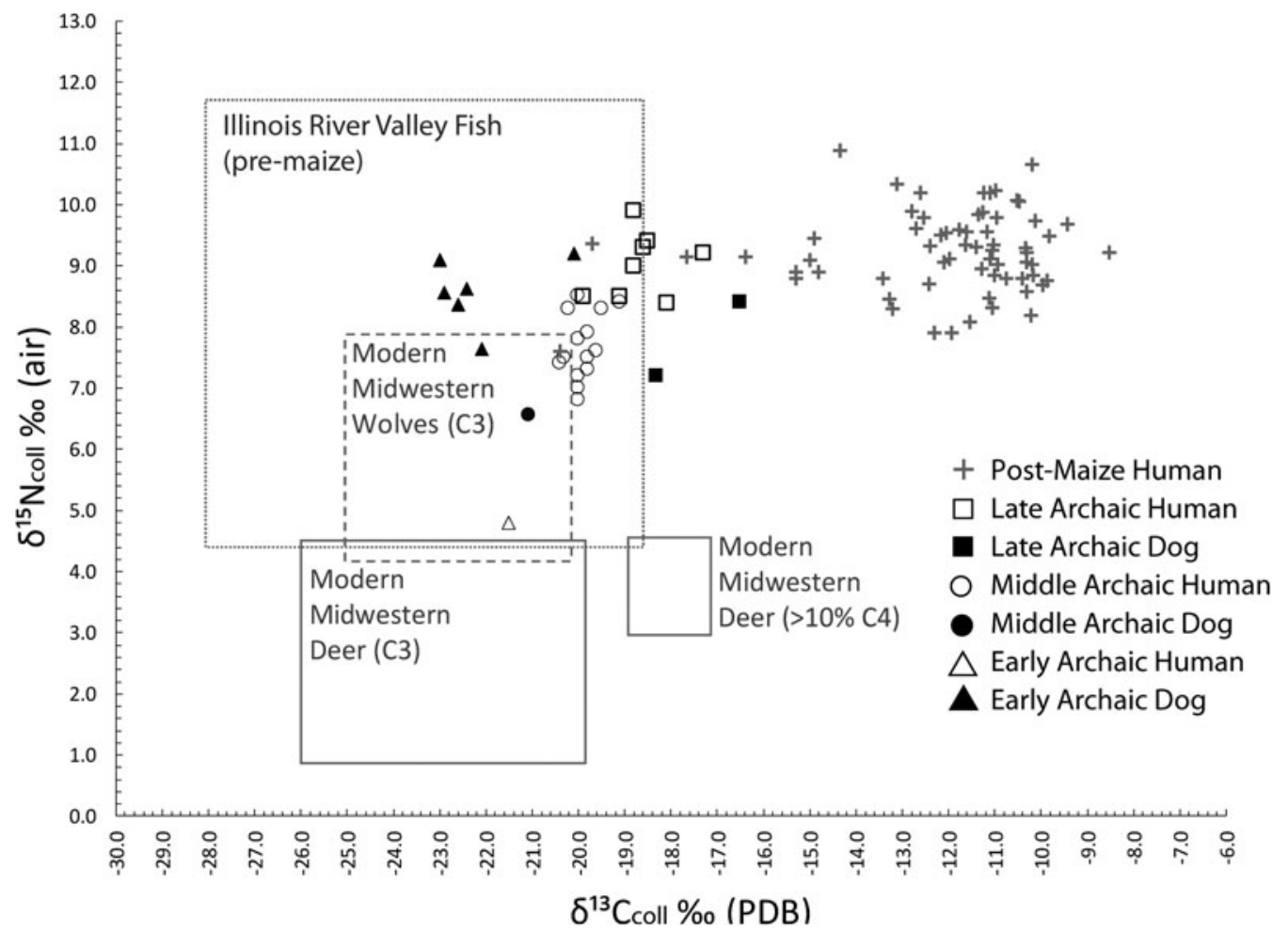

Figure 8. Early Archaic $\operatorname{dog} \delta^{13} \mathrm{C}_{\text {coll }}$ and $\delta^{15} \mathbf{N}_{\text {coll }}$ values, compared to the ranges of modern wolves (Fox-Dobbs et al. 2007), modern deer (Cormie and Schwarcz 1994), and archaeological fish from the Midwest (Brugam et al. 2017). Stable isotope values from Early Archaic (Kaskaskia Mine, $\mathrm{N}=1$; Hargrave et al. 2006), Middle Archaic (Broglio site, $n=16$; Carbaugh et al. 2018), and Late Archaic (Tree Row site, $n=8$; Fort et al. 2015) humans, two Late Archaic dogs from the Tree Row site (Fort et al. 2015), and post-maize human diets ( $N=64$; Hedman et al. 2002) are also included for comparison. All illustrated samples are from the Illinois River valley or the American Bottom. See Supplemental Table 4.

Holocene is relatively elevated compared to terrestrial herbivores and carnivores, suggesting riverine resources were common in diets throughout the region. The primary axis of change throughout the Holocene in both humans and dogs is in $\delta^{13} \mathrm{C}$ values. We interpret this as a general landscape transition to $\mathrm{C}_{4}$ tallgrass prairie after the Early Archaic (also see Nelson et al. 2006), followed by increasing amounts of maize in human and dog diets during the Woodland and Mississippian periods (Hedman et al. 2002). Future establishment of a local early Holocene isotopic baseline for the Illinois valley is needed before we can further understand the role of dogs within the local food web.

\section{Conclusions}

The approximately 10,000-year-old Stilwell II and Koster dogs introduces a gap greater than
4,500 years between these earliest dog remains and the proposed initial migration into the Americas. This is consistent with genomic analyses proposing North American dog populations originated around 10,000 cal BP (Witt et al. 2015), though others suggest an earlier split from Eurasian dogs (Ní Leathlobhair et al. 2018; Thalmann et al. 2013). Recent DNA analysis suggests precontact American dogs, including those from Koster, shared a common ancestor with eastern Siberian dogs around 15,600 years ago and saw an internal population split roughly 1,000 years later (Ní Leathlobhair et al. 2018), though it is not clear on which side of Beringia that split occurred. It is possible that the arrival of the first human populations into the Americas predated their access to Eurasian domesticated dogs, and thus they arrived without them. In this scenario, dogs may have arrived with later genetically indistinguishable migrating Siberian 
groups (as part of ongoing "migratory dribbles"; Meltzer 2009:200) before the flooding of the Bering Land Bridge 11,000 years ago (Jakobsson et al. 2017) but were not part of the very first pulse of migration into the Americas.

The earliest New World domesticated dogs appearing in the midcontinent around 10,000 years ago presents a conundrum both temporally and spatially, but the current absence of Paleoindian dogs in the American West may be the result of several factors. Evidence of earlier dogs in western North America may be unrecognized, despite the number of Clovis, Western Stemmed Tradition, and earlier sites (Erlandson et al. 2011; Smallwood and Jennings 2014; Stanford and Stenger 2014). Some regions still have few early sites, and the ephemeral nature of some sites (e.g., procurement or satellite camps) may constrain the discovery of dog remains (Erlandson et al. 2011; Fiedel 2005). If early dog remains are being encountered, they may not be identified as dogs, particularly given the often limited and poorly preserved nature of early skeletal material and the difficulty in distinguishing early dogs from wolves (Perri 2016a) and coyotes. The few specimens that have been tentatively proposed as Paleoindian dogs (e.g., Grayson et al. 1988; Haag 1970; Walker and Frison 1982) have not been reevaluated, leaving their taxonomy unclear. These potential dogs are only slightly older than the Stilwell II and Koster specimens, leaving any dogs associated with the earliest human migration in the Americas undiscovered. Finally, it is possible that domesticated dogs entering the Americas with human groups facilitated rapid movement into the midcontinent, leaving little trace in western North America.

While an in situ domestication of North American wolves has been raised as a possibility (Koop et al. 2000; Witt et al. 2015), this has been rejected by several genetic analyses (Freedman et al. 2014; Leonard et al. 2002; Ní Leathlobhair et al. 2018; Vilà et al. 1997; VonHoldt et al. 2010). Some North American archaeological dog specimens show genetic similarities with North American wolves (Koop et al. 2000; Witt et al. 2015); however, this is likely the result of admixture rather than North American wolf domestication. Additional work on ancient
American canids, particularly the inclusion of more ancient North American wolf and coyote reference specimens, will further clarify this issue.

Identification of earlier Paleoindian dogs, if they exist, will require distinguishing them from wild canid taxa. This has proven a difficult task, as seen from debates regarding proposed early dogs in the Paleolithic record of Eurasia (Boudadi-Maligne and Escarguel 2014; Crockford and Kuzmin 2012; Drake et al. 2015; Germonpré, Sablin et al. 2015; Ovodov et al. 2011; Perri 2016a). Differentiation between wild and domestic canids has been based primarily on morphological traits, often requiring wellpreserved craniodental material. The validity of these traits for distinguishing domestication is also questionable, given the morphological plasticity of Canis (Ameen et al. 2017; Drake et al. 2017; Janssens et al. 2016; Morey and Jeger 2015). Substantial introgression between newly arriving Eurasian dogs and North American wolves and coyotes likely contributed significantly to American dog ancestry as well, as suggested at Koster (Ní Leathlobhair et al. 2018). This potentially extensive introgression, particularly in the case of early coy-dogs, may contribute to the misidentification of these specimens in the archaeological record. Though some past research has emphasized apparent introgression between ancient dogs and coyotes or wolves (Valadez et al. 2006; Walker and Frison 1982), the issue of early hybridization warrants more attention in future studies.

Analysis of ancient DNA is increasingly being used to identify domesticated dogs (Druzhkova et al. 2013; Frantz et al. 2016; Larson et al. 2012), but such analyses require adequately preserved skeletal material, and results are subject to interpretation (Ding et al. 2012; Savolainen et al. 2002; Skoglund et al. 2015; Thalmann et al. 2013). Increasingly, techniques that do not rely on ancient DNA preservation or the preservation of pristine specimens such as complete crania are allowing researchers to document individual life histories of canids, improving chances of identifying individuals in close contact with humans. These techniques include investigating paleopathology and trauma to clarify, for example, pack loading and mistreatment (Lawler et al. 2016; Losey et al. 2014), and 
geometric morphometrics (GM) to detect biomechanical differences among canids (Drake et al. 2015; Drake et al. 2017; Evin et al. 2016). Dietary analysis of stable isotopes may also help to identify early canids in close contact with humans (Ewersen et al. 2018). Ultimately, a combination of these methods will best promote the identification of the earliest domesticated dogs (and other domesticated species).

The Stilwell II and Koster dogs were contemporaneous medium-sized adults with very active lifestyles and surprisingly varied morphologies for their proximity in space and time. Their stable isotope values reflect a $\mathrm{C}_{3}$-dominated Early Archaic landscape and substantial freshwater fish consumption. Early American dogs likely played key cultural and ecological roles in the movement and adaptation of migrating human populations, and their intentional burial suggests they were important to human domesticity in the Americas by 10,000 years ago. Similar burials in other temperate hunter-gatherer contexts have been associated with the dog's importance in hunting techniques as people adapted to changing environments and prey during the PleistoceneHolocene transition, and with the dog's subsequent elevation in social status (Perri 2014, 2016b). The intentional burial of the Koster and Stilwell II dogs may reflect a similar importance of hunting dogs in the deciduous forest environment of the midcontinent.

The dating of the Stilwell II dog to around 10,000 years ago, coinciding with similar dates for the Koster dogs, adds a further early specimen to the precontact dog record and identifies the lower Illinois River valley as an important site of early North American domestic dog activity. These new dates potentially extend the presence of North American dogs into the Paleoindian period. They also confirm the Stilwell II and Koster specimens as the earliest securely identified skeletal remains of dogs in the Americas and the earliest examples of intentional individual dog burials in the worldwide archaeological record. ${ }^{1}$ Future evaluation of faunal remains from Clovis, Western Stemmed, and earlier sites may further identify domesticated dogs in the earlier Paleoindian record, supporting their arrival with the first human migrations into the Americas. Alternatively, the timing and location of these earliest dogs may suggest a later arrival with subsequent early human migrations.

\section{Notes}

1. Although an individual dog burial has been reported from the Siberian Beringian site of Ushki-1 (layer 6 [Dikov 1979]) that dates to around 12,000 years ago (Goebel et al. 2010), by all accounts these remains were identified only via photograph in the 1970 s and were presumably not collected due to poor preservation conditions at the site (Ted Goebel, personal communication 2018; Pitulko and Kasparov 2017), thus they have never been confirmed as a dog or directly dated.

Acknowledgements. We thank the Illinois State Museum for access to the faunal collections; the Center for American Archeology for use of the Koster excavation photograph; and Doug Carr and Claire Martin for additional material photographs. We also thank Bonnie Styles, Dee Ann Watt, Mike Wiant, Beckie Dyer, Mike Kolb, Jim Theler, Kris Hedman, and Tom Emerson for their assistance as well as Ken Ames, Torben Rick, Ted Goebel, and the anonymous reviewers for their helpful comments on the manuscript. ISAS would particularly like to acknowledge Bob Perino for the generous donation of his father's material from the Stilwell II site. Funding was provided by the Illinois State Museum Society, the ETSU Center of Excellence in Paleontology, the Rosemary Cramp Travel Fund, and the R. Bruce McMillan Museum Research Internship (A.R.P).

Data Availability Statement. Morphosource provides 3-D mandible models of the Koster F2256 dog (http://www. morphosource.org/Detail/SpecimenDetail/Show/specimen_id/ 10494) and the Stilwell II dog (http://www.morphosource. org/Detail/SpecimenDetail/Show/specimen_id/10495).

Supplemental Materials. For supplementary material accompanying this paper, visit https://doi.org/10.1017/aaq. 2018.74

Supplemental Text. The Stilwell II Site.

Supplemental Table 1. Measurements of the Stilwell II and Koster Dogs.

Supplemental Table 2. Skeletal Pathology Observations of the Stilwell II Dog.

Supplemental Table 3. Supplemental Table 3. Comparative Measurements on "Length of Carnassial $\mathrm{M}_{1}$ " (VDD13L) and "Height of Mandible Behind $\mathrm{M}_{1}$ " (VDD19).

Supplemental Table 4. Stable Isotope Results of Archaeological Dog, Archaeological Human, Archaeological Fish, Modern Deer, and Modern Wolf.

\section{References Cited}

Ahler, Steven R.

1993 Stratigraphy and Radiocarbon Chronology of Modoc Rock Shelter, Illinois. American Antiquity 58:462-489. 
Ameen, Carly, Ardern Hulme-Beaman, Allowen Evin, Mietje Germonpré, Kate Britton, Thomas Cucchi, Greger Larson, and Keith Dobney

2017 A Landmark-Based Approach for Assessing the Reliability of Mandibular Tooth Crowding as a Marker of Dog Domestication. Journal of Archaeological Science 85:41-50.

Axelsson, Erik, Abhirami Ratnakumar, Maja-Louise Arendt, Khurram Maqbool, Matthew T. Webster, Michele Perloski, Olof Liberg, Jon M. Arnemo, Åke Hedhammar, and Kerstin Lindblad-Toh

2013 The Genomic Signature of Dog Domestication Reveals Adaptation to a Starch-Rich Diet. Nature 495 (7441):360.

Baker, Richard G., Louis J. Maher, Craig A. Chumbley, and Kent L. Van Zant

1992 Patterns of Holocene Environmental Change in the Midwestern United States. Quaternary Research 37:379-389.

Beebe, B. F.

1980 A Domestic Dog (Canis familiaris L.) of Probable Pleistocene Age from Old Crow, Yukon Territory, Canada. Canadian Journal of Archaeology=Journal Canadien d'Archéologie 4:161-168.

Boudadi-Maligne, Myriam, and Gilles Escarguel

2014 A Biometric Re-evaluation of Recent Claims for Early Upper Palaeolithic Wolf Domestication in Eurasia. Journal of Archaeological Science 45:80-89.

Bozell, John R.

1988 Changes in the Role of the Dog in ProtohistoricHistoric Pawnee Culture. Plains Anthropologist 33:95-111.

Braje, Todd J., Tom D. Dillehay, Jon M. Erlandson, Richard G. Klein, and Torben C. Rick

2017 Finding the First Americans. Science 358 (6363):592-594

Brown, Sarah K., Christyann M. Darwent, and Benjamin N. Sacks

2013 Ancient DNA Evidence for Genetic Continuity in Arctic Dogs. Journal of Archaeological Science 40 (2):1279-1288

Brown, James A., and Robert K. Vierra

1983 What Happened in the Middle Archaic? Introduction to an Ecological Approach to Koster Site Archaeology. Academic Press, Orlando, Florida.

Brugam, Richard B., Kayla Little, Luci Kohn, Paul Brunkow, Gregory Vogel, and Terrance Martin

2017 Tracking Change in the Illinois River Using Stable Isotopes in Modern and Ancient Fishes. River Research and Applications 33(3):341-352.

Buikstra, Jane E., Jerome C. Rose, and George R. Milner

1994 A Carbon Isotopic Perspective on Dietary Variation in Late Prehistoric Western Illinois. In Agricultural Origins and Development in the Midcontinent, edited by William Green pp. 15-170. Office of the State Archaeologist, Iowa City, Iowa.

Butzer, Karl W.

1978 Changing Holocene Environments at the Koster Site: A Geo-Archaeological Perspective. American Antiquity 43:408-413.

Camarós, Edgard, Susanne C. Münzel, Marián Cueto, Florent Rivals, and Nicholas J. Conard

2016 The Evolution of Paleolithic Hominin-Carnivore Interaction Written in Teeth: Stories from the Swabian Jura (Germany). Journal of Archaeological Science: Reports 6:798-809.
Carbaugh, Aimee E., Amanda Headley, and Matthew Fort

2018 Human Remains Analysis Results and Interpretation. In The Broglio Site: A Late Middle Archaic Habitation and Mortuary Site in the Big Muddy Watershed. Illinois State Archaeological Survey Research Report No. 49. Prairie Research Institute, University of Illinois at Urbana-Champaign.

Cormie, A. B., and H. P. Schwarcz

1994 Stable Isotopes of Nitrogen and Carbon of North American White-Tailed Deer and Implications for Paleodietary and Other Food Web Studies. Palaeogeography, Palaeoclimatology, Palaeoecology 107(3-4):227241.

Crockford, Susan J., and Yaroslav Kuzmin

2012 Comments on Germonpré et al., Journal of Archaeological Science 36, 2009 "Fossil Dogs and Wolves from Palaeolithic Sites in Belgium, the Ukraine and Russia: Osteometry, Ancient DNA and Stable Isotopes", and Germonpré, Lázkičková-Galetová, and Sablin, Journal of Archaeological Science 39, 2012 "Palaeolithic Dog Skulls at the Gravettian Předmostí Site, the Czech Republic". Journal of Archaeological Science 39 (8):2797-2801.

Darwent, Christann M., and J. Eric Gilliland

2001 Osteological Analysis of Domestic Dogs from Burials in Southern Missouri. Missouri Archaeology 62:149-169.

DeBowes, Linda J., Derek Mosier, E. Logan, C. E. Harvey, S. Lowry, and D. C. Richardson

1996 Association of Periodontal Disease and Histologic Lesions in Multiple Organs from 45 Dogs. Journal of Veterinary Dentistry 13(2):57-60.

Dikov, Nikolay N.

1979 Drevniye kul'tury severo-vostochnoy Azii. Aziya na styke s Amerikoy $\mathrm{v}$ drevnosti [Ancient Cultures of Northeast Asia: Asia at the Junction with America in Antiquity], Nauka, Moscow (in Russian).

Dillehay, Tom D., Carlos Ocampo, José Saavedra, Andre Oliveira Sawakuchi, Rodrigo M. Vega, Mario Pino, Michael B. Collins, Linda Scott Cummings, Iván Arregui, Ximena S. Villagran, Gelvam A. Hartmann, Mauricio Mella, Andrea González, and George Dix

2015 New Archaeological Evidence for an Early Human Presence at Monte Verde, Chile. PLoS ONE 10(11): e0141923. DOI: 10.1371/journal.pone.0141923, accessed June 12, 2018.

Ding, Zhao-Li, Mattias Oskarsson, Arman Ardalan, Helen Angleby, Lars-Göran Dahlgren, Cafer Tepeli, Ewen Kirkness, Peter Savolainen, and Ya-Ping Zhang

2012 Origins of Domestic Dog in Southern East Asia Is Supported by Analysis of Y-chromosome DNA. Heredity 108(5):507.

Doherty, Tim S., Chris R. Dickman, Alistair S. Glen, Thomas M. Newsome, Dale G. Nimmo, Euan G. Ritchie, Abi T. Vanak, and Aaron J. Wirsing.

2017 The Global Impacts of Domestic Dogs on Threatened Vertebrates. Biological Conservation 210:56-59.

Drake, Abby G., Michael Coquerelle, and Guillaume Colombeau

2015 3D Morphometric Analysis of Fossil Canid Skulls Contradicts the Suggested Domestication of Dogs during the Late Paleolithic. Scientific Reports 5:8299. DOI: 10.1038/srep08299, accessed December 1, 2017.

Drake, Abby G., Michael Coquerelle, Pavel A. Kosintsev, Olga P. Bachura, Mikhail Sablin, Andrei V. Gusev, Lacey S. Fleming, and Robert J. Losey

2017 Three-Dimensional Geometric Morphometric 
Analysis of Fossil Canid Mandibles and Skulls. Scientific Reports 7(1):9508.

Druzhkova, Anna S., Olaf Thalmann, Vladimir A. Trifonov, Jennifer A. Leonard, Nadezhda V. Vorobieva, Nikolai D. Ovodov, Alexander S. Graphodatsky, and Robert K. Wayne

2013 Ancient DNA Analysis Affirms the Canid from Altai as a Primitive Dog. PLOS ONE 8(3):e57754.

Easton, Norman A., Glen R. Mackay, Patricia B. Young, Peter Schnurr, and David R. Yesner

2011 Chindadn in Canada? Emergent Evidence of the Pleistocene Transition in Southeast Beringia as Revealed by the Little John Site, Yukon. In From the Yenisei to the Yukon: Interpreting Lithic Assemblage Variability in Late Pleistocene/Early Holocene Beringia, edited by Ted Goebel and Ian Buvit, pp. 289-307, Texas A\&M University Press, College Station.

Emerson, Thomas E., Kristin M. Hedman, and Mary L. Simon

2005 Marginal Horticulturalists or Maize Agriculturalists? Archaeobotanical, Paleopathological, and Isotopic Evidence Relating to Langford Tradition Maize Consumption. Midcontinental Journal of Archaeology 30:67-118.

Erlandson, Jon M., Torben C. Rick, Todd J. Braje, Molly Casperson, Brendan Culleton, Brian Fulfrost, Tracy Garcia, Daniel A. Guthrie, Nicholas Jew, Douglas J. Kennett, Madonna L. Moss, Leslie Reeder, Craig Skinner, Jack Watts, Lauren Willis

2011 Paleoindian Seafaring, Maritime Technologies, and Coastal Foraging on California's Channel Islands. Science 331:1181-1185.

Evin, Allowen, Thibaud Souter, Ardern Hulme-Beaman, Carly Ameen, Richard Allen, Pietro Viacava, Greger Larson, Thomas Cucchi, and Keith Dobney

2016 The Use of Close-Range Photogrammetry in Zooarchaeology: Creating Accurate 3D Models of Wolf Crania to Study Dog Domestication. Journal of Archaeological Science: Reports 9 87-93.

Ewersen, Jörg, Stefan Ziegler, Britta Ramminger, and Ulrich Schmölcke

2018 Stable Isotopic Ratios from Mesolithic and Neolithic Canids as an Indicator of Human Economic and Ritual Activity Journal of Archaeological Science: Reports 17:346-357.

Fiedel, Stuart J.

2005 Man's Best Friend-Mammoth's Worst Enemy? A Speculative Essay on the Role of Dogs in Paleoindian Colonization and Megafaunal Extinction. World Archaeology 37:11-25.

Fort, Matthew A., Kristin M. Hedman, and Stanley H. Ambrose

2016 Stable Isotope Analysis of Diet in a Sample of Human and Mammal Bone. In The Tree Row Site: A Late Archaic Habitation and Mortuary Site in the Central Illinois Valley, edited by Dale L. McElrath and Madeleine G. Evans, pp. 215-221, Illinois State Archaeological Survey, Prairie Research Institute, UrbanaChampaign.

Fox-Dobbs, Kena, J.K. Bump, R.O. Peterson, D. L. Fox, and P.L. Koch

2007 Carnivore-Specific Stable Isotope Variables and Variation in the Foraging Ecology of Modern and Ancient Wolf Populations: Case Studies from Isle Royale, Minnesota, and La Brea. Canadian Journal of Zoology 85(4):458-471.
Frantz, Laurent A., Victoria E. Mullin, Maud Pionnier-Capitan, Ophélie Lebrasseur, Morgane Ollivier, Angela Perri, Anna Linderholm, Valeria Mattiangeli, Matthew D. Teasdale, Evangelos A. Dimopoulos, Anne Tresset, Marilyne Duffraisse, Finbar McCormick, László Bartosiewicz, Erika Gál, Éva A. Nyerges, Mikhail V. Sablin, Stéphanie Bréhard, Marjan Mashkour, Adrian Bălăşescu, Benjamin Gillet, Sandrine Hughes, Olivier Chassaing, Christophe Hitte, Jean-Denis Vigne, Keith Dobney, Catherine Hänni, Daniel G. Bradley, and Greger Larson

2016 Genomic and Archaeological Evidence Suggest a Dual Origin of Domestic Dogs. Science 352(6290): 1228-1231.

Freedman, Adam H., Ilan Gronau, Rena M. Schweizer, Diego Ortega-Del Vecchyo, Eunjung Han, Pedro M. Silva, Marco Galaverni, Zhenxin Fan, Peter Marx, Belen Lorente-Galdos, Holly Beale, Oscar Ramirez, Farhad Hormozdiari, Can Alkan, Carles Vilà, Kevin Squire, Eli Geffen, Josip Kusak, Adam R. Boyko, Heidi G. Parker, Clarence Lee, Vasisht Tadigotla, Adam Siepel, Carlos D. Bustamante, Timothy T. Harkins, Stanley F. Nelson, Elaine A. Ostrander, Tomas Marques-Bonet, Robert K. Wayne, and John Novembre

2014 Genome Sequencing Highlights the Dynamic Early History of Dogs. PLoS Genetics 10(1):e1004016. DOI: 10.1371/journal.pgen.1004016, accessed October 25, 2017.

Froehle, Andrew W., Corina M. Kellner, and Margaret J. Schoeninger

2012 Multivariate Carbon and Nitrogen Stable Isotope Model for the Reconstruction of Prehistoric Human Diet. American Journal of Physical Anthropology 147:352-369.

Germonpré, Mietje, Mikhail V. Sablin, Rhiannon E. Stevens, Robert E.M. Hedges, Michael Hofreiter, Mathias Stiller, and Viviane R. Després

2009 Fossil Dogs and Wolves from Palaeolithic Sites in Belgium, the Ukraine and Russia: Osteometry, Ancient DNA and Stable Isotopes. Journal of Archaeological Science 36:473-490.

Germonpré, Mietje, Mikhail V. Sablin, Viviane Després, Michael Hofreiter, Martina Lázničková-Galetová, Rhiannon E. Stevens, and Mathias Stiller

2013 Palaeolithic Dogs and the Early Domestication of the Wolf: A Reply to the Comments of Crockford and Kuzmin (2012). Journal of Archaeological Science 40 (1):786-792.

Germonpré, Mietje, Martina Lázničková-Galetová, and Mikhail V. Sablin

2012 Palaeolithic Dog Skulls at the Gravettian Předmostí Site, the Czech Republic. Journal of Archaeological Science 39(1): 184-202.

Germonpré, Mietje, Mikhail V. Sablin, Martina LázničkováGaletová, Viviane Després, Rhiannon E. Stevens, Mathias Stiller, and Michael Hofreiter

2015 Palaeolithic Dogs and Pleistocene Wolves Revisited: A Reply to Morey (2014). Journal of Archaeological Science, 54, 210-216.

Germonpré, Mietje, Martina Lázničková-Galetová, Robert J. Losey, Jannikke Räikkönen, and Mikhail V. Sablin

2015 Large Canids at the Gravettian Předmostí Site, the Czech Republic: the Mandible. Quaternary International 359:261-279.

Germonpré, Mietje, Sergey Fedorov, Petr Danilov, Patrik Galeta, Elodie-Laure Jimenez, Mikhail Sablin, 
and Robert J. Losey

2017 Palaeolithic and Prehistoric Dogs and Pleistocene Wolves from Yakutia: Identification of Isolated Skulls. Journal of Archaeological Science 78:1-19.

Goebel, Ted, Sergei B. Slobodin, and Michael R. Waters 2010 New Dates from Ushki-1, Kamchatka, Confirm 13,000 cal BP Age for Earliest Paleolithic Occupation Journal of Archaeological Science 37(10):2640-2649.

Gowlett, John A., R. E. M. Hedges, I. A. Law, and C. Perry 1987 Radiocarbon Dates from the Oxford AMS System: Archaeometry Datelist 5. Archaeometry 29:125-155.

Grayson, Donald K., Paul W. Parmalee, R. Lee Lyman, and Jim I. Mead

1988 Danger Cave, Last Supper Cave, and Hanging Rock Shelter: The Faunas. Anthropological Papers of the American Museum of Natural History Vol. 66(1). American Museum of Natural History, New York.

Haag, William G.

1970 Dog Remains from Hogup Cave. In Hogup Cave, edited by Melvin Aikens, pp. 273-274. University of Utah Anthropological Papers, Volume 84, University of Utah, Salt Lake City.

Hajic, Edwin R.

1990 Koster Site Archaeology I: Stratigraphy and Landscape Evolution (No. 8). Center for American Archeology Press, Kampsville, IL.

Halligan, Jessi J., Michael R. Waters, Angelina Perrotti, Ivy J. Owens, Joshua M. Feinberg, Mark D. Bourne, Brendan Fenerty, Barbara Winsborough, David Carlson, Daniel C. Fisher, Thomas W. Stafford, Jr., and James S. Dunbar 2016 Pre-Clovis Occupation 14,550 Years Ago at the Page-Ladson Site, Florida, and the Peopling of the Americas. Science Advances 2(5):e1600375.DOI:10.1126/ sciadv.1600375, accessed September 20, 2017.

Harcourt, Ralph A.

1974 The Dog in Prehistoric and Early Historic Britain. Journal of Archaeological Science 1(2):151-175.

Hargrave, Eve A., Kristin M. Hedman, and Rebecca Wolf

2006 Isolated Human Burial at the Kaskaskia Mine Site (11R687), Randolph County, Illinois. Transportation Archaeological Research Reports No. 104, Illinois Transportation Archaeological Research Program, Champaign.

Harington, Charles R. (editor)

2003 Annotated Bibliography of Quaternary Vertebrates of Northern North America: With Radiocarbon Dates. University of Toronto Press, Toronto.

Heaton, Tim H.E., John C. Vogel, Gertrud von La Chevallerie, and Gill Collett

1986 Climatic Influence on the Isotopic Composition of Bone Nitrogen. Nature 322:822-824.

Hedman, Kristin, Eve A. Hargrave, and Stanley H. Ambrose 2002 Late Mississippian Diet in the American Bottom: Stable Isotope Analyses of Bone Collagen and Apatite. Midcontinental Journal of Archaeology 27(2):237-271.

Hill, Frederick C.

1972 A Middle Archaic Dog Burial in Illinois. Foundation for Illinois Archaeology, Evanston.

Jakobsson, Martin, Christof Pearce, Thomas M. Cronin, Jan Backman, Leif G. Anderson, Natalia Barrientos, Göran Björk, Helen Coxall, Agatha de Boer, Larry A. Mayer, Carl-Magnus Mörth, Johan Nilsson, Jayne E. Rattray, Christian Stranne, Igor Semiletov, and Matt O'Regan

2017 Post-glacial Flooding of the Bering Land Bridge Dated to $11 \mathrm{cal}$ ka BP Based on New Geophysical and Sediment Records. Climate of the Past 13(8):991-1005.
Janssens, Luc, Inge Spanoghe, Rebecca Miller, and Stefan Van Dongen

2016 Can Orbital Angle Morphology Distinguish Dogs from Wolves? Zoomorphology 135(1):149-158.

Jenkins, Dennis L., Loren G. Davis, Thomas W. Stafford, Jr., Paula F. Campos, Thomas J. Connolly, Linda Scott Cummings, Michael Hofreiter, Bryan Hockett, Katelyn McDonough, Ian Luthe, Patrick W. O'Grady, Mark E. Swisher, Frances White, Bonnie Yates, Robert M. Yohe, II, Chad Yost, and Eske Willerslev

2013 Geochronology, Archaeological Context, and DNA at the Paisley Caves. In Paleoamerican Odyssey, edited by Kelly E. Graf, Caroline V. Ketron, and Michael R. Waters, pp. 485-510. Texas A\&M University Press, College Station.

Katzenberg, M. Anne

1989 Stable Isotope Analysis of Archaeological Faunal Remains from Southern Ontario. Journal of Archaeological Science 16(3):319-329.

Komar, Debra, and Jane E. Buikstra

2003 Differential Diagnosis of a Prehistoric Biological Object from the Koster (Illinois) Site. International Journal of Osteoarchaeology 13(3):157-164.

Koop, Ben F., Maryann Burbidge, Ashley Byun, U. Rink, and Susan J. Crockford

2000 Ancient DNA Evidence of a Separate Origin for North American Indigenous Dogs. BAR International Series 889:271-286.

Lapham, Heather A.

2010 A Baumer Phase Dog Burial from the Kincaid Site in Southern Illinois. Illinois Archaeology 22:437-463.

Larson, Greger, Elinor K. Karlsson, Angela Perri, Matthew T. Webster, Simon Y.W. Ho, Joris Peters, Peter W. Stahl, Philip J. Piper, Frode Lingaas, Merete Fredholm, Kenine E. Comstock, Jaime F. Modiano, Claude Schelling, Alexander I. Agoulnik, Peter A. Leegwater, Keith Dobney, Jean-Denis Vigne, Carles Vilà, Leif Andersson, and Kerstin Lindblad-Toh

2012 Rethinking Dog Domestication by Integrating Genetics, Archeology, and Biogeography. Proceedings of the National Academy of Sciences 109(23):8878-8883.

Lawler, Dennis F., and Evans, R.H.

2016 Evaluation of Femoral Head and Neck New Bone from a Grey Wolf (Canis lupus lupus): When Is It Pathology? Journal of Veterinary Anatomy 9(1):39-46.

Lawler, Dennis F., Chris Widga, David A. Rubin, Jennifer A. Reetz, Richard H. Evans, Basil P. Tangredi, Richard M. Thomas, Terrance J. Martin, Charles Hildebolt, Kirk Smith, Daniel Leib, Jill E. Sackman, James G. Avery, and Gail K. Smith

2016 Differential Diagnosis of Vertebral Spinous Process Deviations in Archaeological and Modern Domestic Dogs. Journal of Archaeological Science 9:54-63.

Lawler, Dennis F., Chris Widga, and Gail Smith

2017 Observations of the Acetabulum and Proximal Femur of the Dire Wolf. Journal of Veterinary Anatomy 10(1):73-83.

Lawrence, Barbara

1967 Early Domestic Dogs. Zeitschrift für Säugetierkunde [Mammalian Biology] 32(1):44-59.

Leonard, Jennifer A., Robert K. Wayne, Jane Wheeler, Raúl Valadez, Sonia Guillén, and Carles Vilà

2002 Ancient DNA Evidence for Old World Origin of New World Dogs. Science 298(5598):1613-1616.

Llamas, Bastien, Lars Fehren-Schmitz, Guido Valverde, Julien Soubrier, Swapan Mallick, Nadin Rohland, Susanne Nordenfelt, Cristina Valdiosera, Stephen M. 
Richards, Adam Rohrlach, Maria Inés Barreto Romero, Isabel Flores Espinoza, Elsa Tomasto Cagigao, Lucía Watson Jiménez, Krzysztof Makowski, Ilán Santiago Leboreiro Reyna, Josefina Mansilla Lory, Julio Alejandro Ballivián Torrez, Mario A. Rivera, Richard L. Burger, Maria Constanza Ceruti, Johan Reinhard, R. Spencer Wells, Gustavo Politis, Calogero M. Santoro, Vivien G. Standen, Colin Smith, David Reich, Simon Y. W. Ho, Alan Cooper, and Wolfgang Haak

2016 Ancient Mitochondrial DNA Provides HighResolution Time Scale of the Peopling of the Americas. Science Advances, 2(4):e1501385. DOI: 10.1126/ sciadv.1501385, accessed on September 13, 2017.

Longin, Robert

1971 New Method of Collagen Extraction for Radiocarbon Dating. Nature 230(5291):241-242.

Losey, Robert J., Benjamin Osipov, Rajitha Sivakumaran, Tatiana Nomokonova, Evgenii V. Kovychev, and Natalia G. Diatchina

2014 Estimating Body Mass in Dogs and Wolves Using Cranial and Mandibular Dimensions: Application to Siberian Canids. International Journal of Osteoarchaeology 25(6):946-959.

Losey, Robert J., K. McLachlin, T. Nomokonova, K. Latham, and L. Harrington

2016 Body Mass Estimates in Dogs and North American Gray Wolves Using Limb Element Dimensions. International Journal of Osteoarchaeology, 27(2):180-191.

Lyman, R. Lee

2013 Paleoindian Exploitation of Mammals in Eastern Washington State. American Antiquity 78:227-247.

McMillan, R. Bruce

1970 Early Canid Burial from the Western Ozark Highland. Science, 167(3922):1246-1247.

Meltzer, David J.

2009 First Peoples in a New World: Colonizing Ice Age America. University of California Press, Berkeley.

Miller, Malcolm E., Howard E. Evans, and George C. Christensen

1979 Miller's Anatomy of the Dog. 2nd ed. WB Saunders Co., Philadelphia

Monzón, J., R. Kays, and D. E. Dykhuizen

2014 Assessment of Coyote-Wolf-Dog Admixture Using Ancestry-Informative Diagnostic SNPs. Molecular Ecology, 23(1):182-197.

Moreno-Mayar, J. Víctor, Ben A. Potter, Lasse Vinner, Matthias Steinrücken, Simon Rasmussen, Jonathan Terhorst, John A. Kamm, Anders Albrechtsen, Anna-Sapfo Malaspinas, Martin Sikora, Joshua D. Reuther, Joel D. Irish, Ripan S. Malhi, Ludovic Orlando, Yun S. Song, Rasmus Nielsen, David J. Meltzer, and Eske Willerslev

2018 Terminal Pleistocene Alaskan Genome Reveals First Founding Population of Native Americans. Nature 553 (7687): 203-207.

Morey, Darcy F.

1992 Size, Shape and Development in the Evolution of the Domestic Dog. Journal of Archaeological Science 19 (2):181-204.

2006 Burying Key Evidence: The Social Bond between Dogs and People. Journal of Archaeological Science 33(2):158-175.

2010 Dogs: Domestication and the Development of a Social Bond. Cambridge University Press, Cambridge.

Morey, Darcy F., and Kim Aaris-Sørensen

2002 Paleoeskimo Dogs of the Eastern Arctic. Arctic 55 (1):44-56.
Morey, Darcy F., and Rujana Jeger

2015 Paleolithic Dogs: Why Sustained Domestication Then? Journal of Archaeological Science: Reports 3:420-428.

2017 From Wolf to Dog: Late Pleistocene Ecological Dynamics, Altered Trophic Strategies, and Shifting Human Perceptions. Historical Biology 29(7):895-903.

Morey, Darcy F., and Michael D. Wiant

1992 Early Holocene Domestic Dog Burials from the North American Midwest. Current Anthropology 33 (2):224-229.

Mueller, Melissa, Ted Goebel, Julie Esdale, and Kelly Graf 2015 Archaeology of the Terminal Pleistocene McDonald Creek Site, Central Alaska. Paper presented at the 80th Annual Meeting of the Society for American Archaeology, San Francisco, California.

Munyikwa, Kennedy, Tammy M. Rittenour, and James K. Feathers

2017 Temporal Constraints for the Late Wisconsinan Deglaciation of Western Canada using Eolian Dune Luminescence Chronologies from Alberta. Palaeogeography, Palaeoclimatology, Palaeoecology 470:147-165.

Mustonen, Anne-Mari, Dennis F. Lawler, Leena Ahola, Tarja Koistinen, Liisa Jalkanen, Jaakko Mononen, Marja-Leena Lamidi, and Petteri Nieminen

2017 Skeletal Pathology of Farm-Reared Obese Juvenile Blue Foxes (Vulpes lagopus). Journal of Veterinary Anatomy 10(2):51-74.

Nelson, David M., Feng Sheng Hu, Eric C. Grimm, B. Brandon Curry, and Jennifer E. Slate

2006 The Influence of Aridity and Fire on Holocene Prairie Communities in the Eastern Prairie Peninsula. Ecology 87(10): 2523-2536.

Neusius, Sarah

1996 Koster Site. In The Oxford Companion to Archaeology, edited by Brian M. Fagan, p. 377. Oxford University Press, Oxford.

Ní Leathlobhair, Máire Ní, Angela R. Perri, Evan K. Irving-Pease, Kelsey E. Witt, Anna Linderholm, James Haile, Ophelie Lebrasseur, Carly Ameen, Jeffrey Blick, Adam R. Boyko, Selina Brace, Yahaira Nunes Cortes, Susan J. Crockford, Alison Devault, Evangelos A. Dimopoulos, Morley Eldridge, Jacob Enk, Kevin Gori, Shyam Gopalakrishnan, Vaughan Grimes, Eric Guiry, Anders J. Hansen, Ardern Hulme-Beaman, John Johnson, Andrew Kitchen, Aleksei K. Kasparov, Young-Mi Kwon, Pavel A. Nikolskiy, Carlos Peraza Lope, Aurélie Manin, Terrance Martin, Michael Meyer, Kelsey Noack Myers, Mark Omura, Jean-Marie Rouillard, Elena Y. Pavlova, Paul Sciulli, Mikkel-Holger S. Sinding, Andrea Strakova, Varvara V. Ivanova, Christopher Widga, Eske Willerslev, Vladimir V. Pitulko, Ian Barnes, M. Thomas P. Gilbert, Keith M. Dobney, Ripan S. Malhi, Elizabeth P. Murchison, Greger Larson, and Laurent A. F. Frantz

2018 The Evolutionary History of Dogs in the Americas. Science 361(6397):81-85.

Olsen, Stanley J.

1985 Origins of the Domestic Dog: the Fossil Record. University of Arizona Press, Tucson.

Ovodov, Nikolai D., Susan J. Crockford, Yaroslav V. Kuzmin, Thomas FG Higham, Gregory WL Hodgins, and Johannes van der Plicht

2011 A 33,000-Year-Old Incipient Dog from the Altai Mountains of Siberia: Evidence of the Earliest Domestication Disrupted by the Last Glacial Maximum. PLOS ONE 
6(7):e22821. DOI: 10.1371/journal.pone.0022821, accessed on September 13, 2017.

Perino, Gregory

1970 The Stilwell II Site, Pike County, Illinois. Central States Archaeological Journal 17(3):118-122.

1977 Points and Barbs: an Editorial. Central States Archaeological Journal 46(4):99-100.

Perri, Angela

2014 Global Hunting Adaptations to Early Holocene Temperate Forests: Intentional Dog Burials as Evidence of Hunting Strategies. PhD dissertation, Department of Archaeology, Durham University.

2016a A Wolf in Dog's Clothing: Initial Dog Domestication and Pleistocene Wolf Variation. Journal of Archaeological Science 68:1-4.

2016b Hunting Dogs as Environmental Adaptations in Jōmon Japan. Antiquity 90(353):1166-1180.

2017 A Typology of Dog Deposition in Archaeological Contexts. In Economic Zooarchaeology: Studies in Hunting, Herding and Early Agriculture, edited by Peter Rowley-Conwy, Dale Serjeantson, and Paul Halstead, pp. 89-99. Oxbow Books, Oxford.

Perri, Angela R., Geoffrey M. Smith, and Marjolein D. Bosch 2015 Comment on "How Do You Kill 86 Mammoths? Taphonomic Investigations of Mammoth Megasites" by Pat Shipman. Quaternary International 368(11): 38-46.

Pitulko, Vladimir V., and Aleksey K. Kasparov

2017 Archaeological Dogs from the Early Holocene Zhokhov Site in the Eastern Siberian Arctic. Journal of Archaeological Science: Reports 13:491-515.

Polischuk, S., K. Hobson, and M. Ramsay

2001 Use of Stable-Carbon and -Nitrogen Isotopes to Assess Weaning and Fasting in Female Polar Bears and Their Cubs. Canadian Journal of Zoology 79: 499-511.

Potter, Ben A., Joshua D. Reuther, Vance T. Holliday, Charles E. Holmes, D. Shane Miller, and Nicholas Schmuck

2017 Early Colonization of Beringia and Northern North America: Chronology, Routes, and Adaptive Strategies. Quaternary International 444(B): 36-55.

Reimer, Paula J., Edouard Bard, Alex Bayliss, J. Warren Beck, Paul G. Blackwell, Christopher Bronk Ramsey, Caitlin E. Buck, Hai Cheng, R. Lawrence Edwards, Michael Friedrich, Pieter M. Grootes, Thomas P. Guilderson, Haflidi Haflidason, Irka Hajdas, Christine Hatté, Timothy J. Heaton, Dirk L. Hoffmann, Alan G. Hogg, Konrad A. Hughen, K. Felix Kaiser, Bernd Kromer, Sturt W. Manning, Mu Niu, Ron W. Reimer, David A. Richards, E. Marian Scott, John R. Southon, Richard A. Staff, Christian S. M. Turney, and Johannes van der Plicht

2013 IntCal13 and MARINE13 Radiocarbon Age Calibration Curves 0-50000 years calBP. Radiocarbon 55 (4):1869-1887.

Sablin, Mikhail, and Gennady Khlopachev

2002 The Earliest Ice Age Dogs: Evidence from Eliseevichi. Current Anthropology 43(5):795-799.

Saunders, Jeffrey J., and Edward B. Daeschler

1994 Descriptive Analyses and Taphonomical Observations of Culturally-Modified Mammoths Excavated at "The Gravel Pit," Near Clovis, New Mexico in 1936. Proceedings of the Academy of Natural Sciences of Philadelphia 145:1-28.

Savolainen, Peter, Ya-ping Zhang, Jing Luo, Joakim Lundeberg, and Thomas Leitner

2002 Genetic Evidence for an East Asian Origin of Domestic Dogs Science 298(5598):1610-1613.
Schober, Teresa

1998 Reinvestigation of Maize Introduction in WestCentral Illinois: A Stable Isotope Analysis of Bone Collagen and Apatite Carbonate from Late Archaic to Mississippian Times. Master's thesis, Department of Anthropology, University of Illinois at UrbanaChampaign, Urbana.

Schoeninger, Margaret J., and Michael J. DeNiro

1984 Nitrogen and Carbon Isotopic Composition of Bone Collagen from Marine and Terrestrial Animals. Geochimica et Cosmochimica Acta 48(4):625-639.

Schwartz, Marion

1998 A History of Dogs in the Early Americas. Yale University Press, New Haven, Connecticut.

Shannon, Laura M., Ryan H. Boyko, Marta Castelhano, Elizabeth Corey, Jessica J. Hayward, Corin McLean, Michelle E. White, Mounir Abi Said, Baddley A. Anita, Nono Ikombe Bondjengo, Jorge Calero, Ana Galov, Marius Hedimbi, Bulu Imam, Rajashree Khalap, Douglas Lally, Andrew Masta, Kyle C. Oliveira, Lucía Pérez, Julia Randall, Nguyen Minh Tam, Francisco J. Trujillo-Cornejo, Carlos Valeriano, Nathan B. Sutter, Rory J. Todhunter, Carlos D. Bustamante, and Adam R. Boyko

2015 Genetic Structure in Village Dogs Reveals a Central Asian Domestication Origin. Proceedings of the National Academy of Sciences 112(44):13639-13644.

Shipman, Pat

2015 How Do You Kill 86 Mammoths? Taphonomic Investigations of Mammoth Megasites. Quaternary International 359:38-46.

Skoglund, Pontus, and David Reich

2016 A Genomic View of the Peopling of the Americas. Current Opinion in Genetics \& Development 41:27-35.

Skoglund, Pontus, Erik Ersmark, Eleftheria Palkopoulou, and Love Dalén

2015 Ancient Wolf Genome Reveals an Early Divergence of Domestic Dog Ancestors and Admixture into HighLatitude Breeds. Current Biology 25(11):1515-1519.

Smallwood, Ashley M., and Thomas Jennings (editors)

2014 Clovis: on the Edge of a New Understanding. Texas A\&M University Press, College Station.

Stanford, Dennis J.

1978 The Jones-Miller Site: An Example of Hell Gap Bison Procurement Strategy. Plains Anthropologist 23 (82):90-97.

Stanford, Dennis J., and Alison Stenger (editors)

2014 Pre-Clovis in the Americas: International Science Conference Proceedings Held at the Smithsonian Institution, Washington, DC. CreateSpace Independent Publishing Platform.

Stuiver, M., Paula J. Reimer, and R. W. Reimer

2017 CALIB 7.1. Electronic document, http://calib.org, accessed July 12, 2017.

Styles, Bonnie W., and R. Bruce McMillan

2009 Archaic Faunal Exploitation in the Prairie Peninsula and Surrounding Regions of the Midcontinent. In Archaic Societies: Diversity and Complexity Across the Midcontinent, edited by Thomas E. Emerson, Dale L. McElrath, and Andrew C. Fortier, pp. 39-80. SUNY Press, Albany, New York.

Thalmann, Olaf, Beth Shapiro, Pin Cui, Verena J. Schuenemann, Susanna K. Sawyer, D. L. Greenfield, Mietje B. Germonpré, Mikhail V. Sablin, F. López-Giráldez, X. Domingo-Roura, Hannes Napierala, H-P. Uerpmann, D. M. Loponte, A. A. Acosta, L. Giemsch, Ralf W. Schmitz, 
Brian Worthington, Jane E. Buikstra, A. Druzhkova, A. S. Graphodatsky, Nikolai D. Ovodov, N. Wahlberg, Adam H. Freedman, R. M. Schweizer, K. P. Koepfli, Jennifer A. Leonard, Matthias Meyer, Johannes Krause, Svante Pääbo, R. E. Green, and Robert K. Wayne

2013 Complete Mitochondrial Genomes of Ancient Canids Suggest a European Origin of Domestic Dogs. Science 342(6160):871-874.

Tieszen, Larry L.

1991 Natural Variations in the Carbon Isotope Values of Plants: Implications for Archaeology, Ecology, and Paleoecology. Journal of Archaeological Science 18 (3):227-248.

Tieszen, Larry L., and Tim Fagre

1993 Effect of Diet Quality and Composition on the Isotopic Composition of Respiratory CO2, Bone Collagen, Bioapatite, and Soft Tissues. In Prehistoric Human Bone: Archaeology at the Molecular Level, edited by Joseph B. Lambert and Gisela Grupe, pp. 121-155. Springer-Verlag, Berlin.

Tito, Raul Y., Samuel L. Belknap, Kristin D. Sobolik, Robert C. Ingraham, Lauren M. Cleeland, and Cecil M. Lewis

2011 Brief Communication: DNA from Early Holocene American Dog. American Journal of Physical Anthropology 145(4):653-657.

Tuross, Noreen, Marilyn Fogel, and P. E. Hare

1988 Variability in the Preservation of the Isotopic Composition of Collagen from Fossil Bone. Geochimica et Cosmochimica Acta 52(4):929-935.

Valadez, Raul, Bernardo Rodríguez, Linda Manzanilla, and Samuel Tejeda

2006 Dog-Wolf Hybrid Biotype Reconstruction from the Archaeological City of Teotihuacan in Prehispanic Central Mexico. In Dogs and People in Social, Working, Economic or Symbolic Interaction, edited by Lynn M. Snyder and Elizabeth A. Moore, pp. 121-131. Oxbow Books, Oxford.

van Asch, Barbara, Ai-bing Zhang, Mattias C. R. Oskarsson, Cornelya F. C. Klütsch, António Amorim, and Peter Savolainen

2013 Pre-Columbian Origins of Native American Dog Breeds, with Only Limited Replacement by European Dogs, Confirmed by mtDNA Analysis. Proceedings of the Royal Society B 280(1766):20131142. DOI: 10.1098/rspb.2013.1142, accessed August 28, 2017.

Vilà, Carles, Peter Savolainen, Jesús E. Maldonado, Isabel R. Amorim, John E. Rice, Rodney L. Honeycutt, Keith A. Crandall, Joakim Lundeberg, and Robert K. Wayne

1997 Multiple and Ancient Origins of the Domestic Dog. Science 276(5319):1687-1689.

Von den Driesch, Angela

1976 A Guide to the Measurement of Animal Bones from Archaeological Sites: as Developed by the Institut für Palaeoanatomie, Domestikationsforschung und Geschichte der Tiermedizin of the University of Munich (Vol. 1). Peabody Museum Press, Cambridge, Massachusetts.

vonHoldt, Bridgett, John P. Pollinger, Kirk E. Lohmueller, Eunjung Han, Heidi G. Parker, Pascale Quignon, Jeremiah D. Degenhardt, Adam R. Boyko, Dent A. Earl, Adam Auton, Andy Reynolds, Kasia Bryc, Abra Brisbin, James C. Knowles, Dana S. Mosher, Tyrone C. Spady, Abdel Elkahloun, Eli Geffen, Malgorzata Pilot, Wlodzimierz Jedrzejewski, Claudia Greco, Ettore Randi, Danika Bannasch, Alan Wilton, Jeremy Shearman, Marco Musiani, Michelle Cargill, Paul G. Jones, Zuwei Qian, Wei Huang, Zhao-Li Ding, Ya-ping Zhang, Carlos D. Bustamante, Elaine A. Ostrander, John Novembre, and Robert K. Wayne

2010 Genome-wide SNP and Haplotype Analyses Reveal a Rich History Underlying Dog Domestication. Nature 464(7290):898.

Walker, Danny N., and George C. Frison

1982 Studies on Amerindian Dogs, 3: Prehistoric Wolf/ Dog Hybrids from the Northwestern Plains. Journal of Archaeological Science 9(2):125-172.

Walker, Renee B., Darcy F. Morey, and John. H. Relethford 2005 Early and Mid-Holocene Dogs in Southeastern North America: Examples from Dust Cave. Southeast Archaeology 24:83-92

Wang, Guo-Dong, Weiwei Zhai, He-Chuan Yang, Lu Wang, Li Zhong, Yan-Hu Liu, Ruo-Xi Fan, Ting-Ting Yin, Chun-Ling Zhu, Andrei D Poyarkov, David M Irwin, Marjo K. Hytönen, Hannes Lohi, Chung-I Wu, Peter Savolainen, and Ya-Ping Zhang

2016 Out of Southern East Asia: The Natural History of Domestic Dogs across the World. Cell Research 26 (1):21.

Warren, Diane M.

2000 Paleopathology of Archaic Dogs from the North American Southeast. In Dogs Through Time: An Archaeological Perspective, edited by Susan J. Crockford, pp. 93-104. BAR International Series 889. British Archaeological Reports, Oxford.

Wayne, Robert K., and Susan M. Jenks

1991 Mitochondrial DNA Analysis Implying Extensive Hybridization of the Endangered Red Wolf (Canis rufus). Nature 351(6327):565-568.

Witt, Kelsey E., Kathleen Judd, Andrew Kitchen, Colin Grier, Timothy A. Kohler, Scott G. Ortman, Brian M. Kemp, and Ripan S. Malhi

2015 DNA Analysis of Ancient Dogs of the Americas: Identifying Possible Founding Haplotypes and Reconstructing Population Histories. Journal of Human Evolution 79:105-118.

Submitted March 3, 2018; Revised July 20, 2018; Accepted July 24, 2018 